\title{
SUSANA MUÑOZ, YMPRESSORA DE LOS LIBROS DE MUSICA, AND DIEGO DE BRUCEÑA'S LIBRO DE CANTO DE MISAS Y MAGNIFICAS Y MOTETES Y UNA SALUE (SALAMANCA, 1620)
}

\author{
SUSANA MUÑOZ, YMPRESSORA DE LOS LIBROS DE MUSICA, \\ Y EL LIBRO DE CANTO DE MISAS Y MAGNIFICAS Y MOTETES \\ $Y$ UNA SALUE (SALAMANCA, 1620) DE DIEGO DE BRUCEÑA
}

\author{
Michael Noone \\ michael.noone@bc.edu \\ ORCID ID: 0000-0002-4710-5403
}

In memoriam José López-Calo, S. J. (†2020)

\section{Resumen}

Entre sus muchos tesoros, la Catedral de Miranda do Douro en el distrito de Bragança en Portugal alberga el único ejemplar conocido del libro de polifonía de Diego de Bruceña (Salamanca: Antonio Vázquez, 1620). Este libro de coro conserva el conjunto más significativo de las obras de un compositor cuyas composiciones se pensaba que estaban casi completamente perdidas. El estudio detenido del libro de coro nos permite elaborar una comprensión más detallada y matizada de la impresión de la música sacra, y especialmente de los libros de coro polifónicos, en la Salamanca de las primeras décadas del siglo XVII. Un papel central en la impresión del libro de coro lo desempeñó Susana Muñoz, una emprendedora mujer de negocios que, a través de sucesivos matrimonios estratégicos con figuras clave del floreciente comercio de la imprenta de Salamanca, mantuvo una imprenta que en el período 1602-1625 emitió más de 120 títulos. Este artículo aprovecha el 400 aniversario de la producción del libro de coro para introducir esta colección de Bruceña en el contexto más amplio de la impresión musical en Salamanca en el período 1607-1620, y para esbozar los contornos más amplios de la contribución de Susana Muñoz y sus tres maridos.

\section{Palabras clave}

Diego de Bruceña (1567-1623), Susana Muñoz (fl. 15801625), polifonía, imprenta musical, música española siglo XVII.

The story of Susana Muñoz, one of early modern Spain's most prolific printers of sacred music, is one that is waiting to be told. The protagonist was an enterprising

\begin{abstract}
Among its many treasures, the Cathedral of Miranda do Douro in the district of Bragança in Portugal houses the only known exemplar of Diego de Bruceña's book of polyphony (Salamanca: Antonio Vázquez, 1620). This choirbook preserves the most significant body of the works of a composer whose compositions were thought to be almost entirely lost. Close study of the choirbook allows us to construct a more detailed and nuanced understanding of the printing of sacred music, and especially the printing of polyphonic choirbooks, in Salamanca in the first decades of the 17th century. A central rôle in the printing of the choirbook was played by Susana Muñoz, an enterprising business woman who, through successive strategic marriages to key figures in Salamanca's thriving printing trade, built a firm that in the period 1602 to 1625 issued more than 120 titles. This article seizes the occasion of the 400th anniversary of the choirbook's production to introduce Bruceña's choirbook within the wider context of music printing in Salamanca in the period 1607-1620, and to sketch the broader contours of the contribution of Susana Muñoz, the three husbands with whom she worked, and all of whom she survived.
\end{abstract}

\section{Keywords}

Diego de Bruceña (1567-1623), Susana Muñoz (fl. 1580$1625)$, polyphony, music printing, 17 th-century Spanish music.

business woman who, through successive strategic marriages to key figures in Salamanca's thriving printing trade, built a firm that in the period 1602 to 1625 issued 
more than 120 titles. ${ }^{1}$ In the 1620 s, the firm's operations were taken over by Jacinto Taberniel, Susana's only son $(† 1641)$, who would later describe himself as 'impresor de la Vniuersidad'. In the period 1607 to 1620 , no fewer than seven atlas-sized choirbooks emerged from the print shop in Salamanca founded by Muñoz's first husband, the Fleming Artus Tavernier. Three of these magnificent polyphonic choirbooks were devoted to music by Sebastián de Vivanco (ca. 1550-1622), three were devoted to music by Juan Esquivel de Barahona (ca. 1563-after 1612), and one - the subject of this article - to music composed by Diego de Bruceña (1567-1623). Taken together, the seven books contain more than 280 Latin liturgical works scored for between four and twelve voices printed on a total of more than 2,300 pages. One of them, Esquivel's Psalmorvm, Hymnorvm, Magnificarvm...Tomvs Secvndvs (1613), with a page count of almost 600 , takes pride of place as one of the largest choirbooks ever printed. In the period 1580 to 1625 , Tavernier, his wife, and their heirs printed twelve books containing music, eleven of them in Salamanca (see Table 1).

\begin{tabular}{|l|c|}
\hline \multicolumn{1}{|c|}{ Publication $^{2}$} & Format \\
\hline Premier Livre des Hymnes anciens, mis & $16^{\circ}$ \\
en vers françois, par Ch. de Navières. & \\
Anvers: Chez Artus Tauernier, à la Rose & \\
d'or, 1580. & \\
\hline
\end{tabular}

1 On women printers in early modern Spain, see Mónica Cortés Corral and Victoria Méndez Viar, "Impresoras madrileñas en el Siglo de Oro: Juana Martínez de Angulo", Anexos de Signo, 4 (2001), pp. 185-211; Vicente Bécares Botas, Avance para una guía del mundo del libro salmantino del siglo XVI (Zamora: Ediciones Monte Casino, 2002), pp. 8-9; Pedro Manuel Cátedra García and Anastasio Rojo Vega, Bibliotecas y lecturas de mujeres (siglo XVI) (Salamanca: Instituto de Historia del Libro y de la Lectura, 2004); and Albert Corbeto, "Las musas ignoradas. Estudio historiográfico del papel de la mujer en el ámbito de la imprenta", in Muses de la Impremta. La dona i les arts del llibre. Segles XVI-XIX, ed. Marina Garone Gravier and Albert Corbeto López (Barcelona: Museu Diocesà de Barcelona and Associació de Bibliòfils de Barcelona, 2009), pp. 21-42.

${ }^{2}$ Bibliographical citations in Table 1 are transcribed from surviving exemplars. In the case of books for which neither a title page nor a colophon survives, hypothetical reconstructions are provided within square brackets. Asterisks indicate books that were acquired by Zamora cathedral during the period of Bruceña's tenure as maestro de capilla (see footnote 26 below).

\begin{tabular}{|c|c|}
\hline Publication & Format \\
\hline $\begin{array}{l}\text { F. Francisci Nauarri, Manvale ad vsvm } \\
\text { chori, ivxta ritvm fratrvm minorvm. } \\
\text { Salmanticæ: Ex Officina Arti Taberniel } \\
\text { Antuerpiani, } 1606 .\end{array}$ & $8^{\circ}$ \\
\hline $\begin{array}{l}\text { Sebastiani de Vivanco Abvlensis, Liber } \\
\text { magnificarvm. Salmanticæ: Ex Officina } \\
\text { typographica Arti Taberniel } \\
\text { Antuerpiani, } 1607 .\end{array}$ & *choirbook \\
\hline $\begin{array}{l}\text { Ioannis Esqvivelis, Missarum...liber } \\
\text { primus. Salmanticæ: Ex Officina } \\
\text { typographica Arti Taberniel } \\
\text { Antuerpiani, } 1608 .\end{array}$ & *choirbook \\
\hline $\begin{array}{l}\text { [Ioannis Esqvivel, Motecta festorum. } \\
\text { Salmanticæ: Excvdebat Artvs } \\
\text { Tabernelivs, 1608.] }\end{array}$ & $*^{*}$ choirbook \\
\hline $\begin{array}{l}\text { [Sebastiani de Vivanco Abvlensis, Liber } \\
\text { missarum. Salmanticæ: Ex Officina } \\
\text { typographica Arti Taberniel } \\
\text { Antuerpiani, 1608.] }\end{array}$ & $*_{\text {choirbook }}$ \\
\hline $\begin{array}{l}\text { Francisco de Montanos, Arte de canto } \\
\text { llano, con entonaciones comunes de } \\
\text { coro, y altar, y otras cosas. Salamanca: } \\
\text { en casa de Francisco de Cea Tesa, a } \\
\text { costa de Andrés López, mercader de } \\
\text { libros, } 1610 .\end{array}$ & $4^{\circ}$ \\
\hline $\begin{array}{l}\text { Ioannis Esqvivel, Psalmorvm, } \\
\text { Hymnorvm, Magnificarvm...Tomvs } \\
\text { Secvndvs. Salmanticæ: Excudebat } \\
\text { Franciscvs de Cea Tesa Cordubensis, } \\
1613 .\end{array}$ & $*_{\text {choirbook }}$ \\
\hline $\begin{array}{l}\text { [Sebastiani de Vivanco Abvlensis, Liber } \\
\text { motectorum]. Salmanticæ: Vidvam } \\
\text { Francisci de Cea Tesa, 1614. }{ }^{3}\end{array}$ & choirbook \\
\hline $\begin{array}{l}\text { Francisco de Montanos, Arte de canto } \\
\text { llano, con entonaciones comunes de } \\
\text { coro, y altar, y otras cosas. Salamanca: } \\
\text { en casa de Susana Muñoz Viuda, a } \\
\text { costa de Andrés López, mercader de } \\
\text { libros, } 1616 .\end{array}$ & $8^{\circ}$ \\
\hline
\end{tabular}

${ }^{3}$ In a forthcoming study I demonstrate that the printing date is 1614 not, as universally accepted 1610 . 


\begin{tabular}{|c|c|}
\hline Publication & Format \\
\hline $\begin{array}{l}\text { [Didacvs de Brvceña, Liber } \\
\text { Magnificarvm, Missarvm, et } \\
\text { motectorvm]. Salma[n]ticæ: Ex officina } \\
\text { typographica Antonij V[ázquez], } \\
16[20] .\end{array}$ & *choirbook \\
\hline $\begin{array}{l}\text { Francisco de Montanos, Arte de canto } \\
\text { llano con entonaciones comunes de } \\
\text { coro y altar, y otras cosas diversas, } \\
\text { como se vera en la tabla. En todo va } \\
\text { acentuado el punto con la letra y } \\
\text { algunas cosas remitidas puestas ad } \\
\text { logum. Salamanca: en casa de Antonio } \\
\text { Vázquez a costa de Antonio López } \\
\text { Calderón, } 1625 \text {. }\end{array}$ & $4^{\circ}$ \\
\hline
\end{tabular}

Table 1. Music books printed by Tavernier, Muñoz, and their heirs.

Until recently, it had been assumed that no copies of the choirbook containing Bruceña's Latin liturgical works had survived. The 2015 announcement, however, by the distinguished art historian and scholar António Rodrigues Mourinho that a damaged exemplar had been located in the Cathedral of Miranda do Douro in the Northeastern Portuguese district of Bragança allows us to fill two significant lacunae in our knowledge of Spanish sacred polyphony in the first quarter of the seventeenth century. ${ }^{4}$

\footnotetext{
${ }^{4}$ See <http://www.rotadascatedrais.com/en/destaques/479miranda-descoberta-obra-de-brucena-na-concatedral> and António Rodrigues Mourinho, "Obra inédita de un músico español en Portugal", Patrimonio. Revista de patrimonio y turismo cultural, 58 (2016), pp. 36-38. I thank Juan Ruiz Jiménez and Alfonso de Vicente for drawing this article to my attention. The Cathedral of Miranda do Douro is now administered by the Museu da Terra de Miranda. I am deeply indebted to Celina Bárbaro Pinto, the Museum's director, for her invitation to study the Bruceña imprint and for her generous hospitality during my visits to Miranda do Douro. I am similarly grateful to the custodians of the many libraries and archives I have visited in the preparation of this article. Special thanks go to José Carlos de Lera Maíllo at the Archivo Diocesano y Catedralicio de Zamora and to Dr. Correia Élia, Director of the Arquivo Distrital de Bragança (Portugal). At the cathedral of Salamanca, I was warmly welcomed by canon-archivist D. Casimiro Muñoz Martín, Raúl Vicente Baz, Pedro José Gómez González, Víctor José Rodríguez Martín, and Patricia Burgueño Rioja. Bonifacio Bartolomé Herrero generously facilitated my studies at the
}

First, we now have a significant body of the works of a composer whose compositions were thought to be almost entirely lost. Second, we are now able to construct a more detailed and nuanced understanding of the printing of sacred music, and especially sacred music in choirbook format, in Salamanca in the first decades of the 17th century. To date, almost everything we know about the Bruceña

cathedral of Segovia. At Oviedo cathedral, archivist Don Agustín Hevia Ballina provided all manner of help, as did the canon-archivist Don Andrés Sánchez Sánchez at Avila’s cathedral. At the cathedral of Burgos, I was kindly assisted by canon-archivist Don Matías Vicario Santamaría and I thank Doña Guadalupe Pérez Ortiz, director of Ecclesiastical Archives in the archdiocese of Mérida-Badajoz. Doña María del Carmen Fuentes Nogales, director of Ecclesiastical Archives in Coria-Cáceres and Plasencia, graciously assisted me at the Cathedral of Coria. I remain grateful to Don Juan Pedro Sánchez Gamero, canon-archivist of Toledo cathedral, to his distinguished predecessors Don Ángel Fernández Collado and the late Don Ramón Gonzálvez Ruiz, and to the inestimable Alfredo Rodríguez González and Isidoro Castañeda Tordera. I also thank Don Alejandro García Torre, canon-archivist at the cathedral of El Burgo de Osma. For his assistance at the Museum Plantin-Moretus in Antwerp, I thank Dirk Imhof, Curator of Books and Archives. Access to the archive of the cathedral of Mexico City was generously facilitated by Salvador Hernández Pech and Lucero Enríquez Rubio. In addition, I gratefully acknowledge the help offered by the staffs of the British Library in London, the Biblioteca Nacional in Madrid, the Archivo Histórico de Protocolos de Madrid, the Biblioteca de Castilla-La Mancha in Toledo, the Archivo Histórico Provincial de Salamanca, the Archivo Histórico Provincial de Zamora, the Archivo Histórico Provincial de Ávila, the Biblioteca de Catalunya in Barcelona and, closer to home, Anne Kenny and her splendid team at Boston College's O'Neill Library and Christian Dupont, librarian of the John J. Burns Library. I am equally indebted to the library of the Hispanic Society of America in New York, and its Curator of Manuscripts and Rare Books, Dr John O’Neill. I thank Soterraña Aguirre for facilitating access to the archive at Valladolid cathedral and Jorge Martín who graciously shared with me his study and transcription of Alonso de Tejeda's third book of motets. Graeme Skinner has also offered assistance and expertise, especially in the preparation of the inventory and the music example in this article. Finally, I offer an enormous vote of thanks to Ascensión Mazuela-Anguita for her assistance with the transcription of archival documents and to the late José López-Calo, S. J. and Emilio Ros-Fábregas for their encouragement and enthusiasm for this project. An earlier version of this article was presented at the 47th Medieval and Renaissance Music Conference in Basel, 3-6 July, 2019. See $<$ https://hispanicpolyphony.eu/source/28270>. 
volume is based on a thorough and meticulously-researched article by Alejandro Luis Iglesias. ${ }^{5}$ It was this article that introduced Susana Muñoz to musicology and while her involvement in the genesis of Bruceña's choirbook was pivotal, it is by no means the beginning of the story of her involvement with the printing of sacred music. Just as Susana Muñoz's leading rôle as a printer of sacred music has been ignored by both musicologists and historians of print, so too has her responsibility for the production of the more than 30 books that bear her personal imprint on their title pages and colophons. These books, whose formats ranged from quarto to folio, and that were printed with texts in Latin and/or Castilian, embrace subjects as diverse as jurisprudence, poetry, religious history, sermons, music theory, and medicine. ${ }^{6}$ The present article seizes the opportunity provided by the 400th anniversary of its production, to introduce Bruceña's choirbook within the wider context of music printing in Salamanca in the period 1607-1620, and to sketch the broader contours of a more comprehensive forthcoming study that will focus on the contribution of Susana Muñoz, the three husbands with whom she worked and all of whom she survived, and the son to whom she finally bequeathed her printing enterprise.

\section{DIEGO DE BRUCEÑA $(\dagger 1622)$ : "RAPAZ, VELLACO, DESVERGONZADO"}

We begin with a brief biographical sketch of a composer who, while held in high esteem for his musical prowess, was a frequent source of scandal and conflict. That Diego de Bruceña was most likely born in or near

\footnotetext{
5 Alejandro Luis Iglesias, "El maestro de capilla Diego de Bruceña (1567/71-1623) y el impreso perdido de su libro de misas, magníficats y motetes (Salamanca: Susana Muñoz, 1620)", in Encomium Musicae. Essays in Honor of Robert J. Snow, ed. David Crawford (Hillsdale, NY: Pendragon Press, 2002), pp. 435-469.

${ }^{6}$ The most complete bibliography of the titles printed by Artus Tavernier, Susana Muñoz, Francisco de Cea Tesa, Antonio Vázquez, and Susana's son Jacinto Taberniel will be found in Alexander Samuel Wilkinson and Alejandra Ulla Lorenzo, eds., Iberian Books Volumes II \& III: Books Published in Spain, Portugal and the New World or elsewhere in Spanish or Portuguese between 1601 and 1650 / Libros Ibéricos volúmenes II y III: Libros publicados en España, Portugal y el Nuevo Mundo o impresos en otros lugares en español o portugués entre 1601 y 1650 (Leiden: Koninklijke Brill NV, 2016). See <https://iberian.ucd.ie/index.php>.
}

Orense, can be deduced from documentary records that place him as a boy chorister, and later as maestro de capilla, at Orense's cathedral. He served as maestro in Orense from 1589 to 1593 and subsequently held chapelmasterships in the cathedrals of Oviedo (1593-1594), León (1594-1600), Burgos (1601-1608), and Zamora (16081622). ${ }^{7}$ One of the principal sources for our knowledge of Bruceña are the Actas capitulares (hereinafter AC) from these five cathedrals in Spain's North West.

We learn, for example, that on 1 August 1594, the dean and chapter of León cathedral wrote to Bruceña, at the time maestro de capilla in the cathedral of Oviedo, offering him the post of maestro in León with an annual salary of 100,000 maravedís. ${ }^{8}$ Less than a year later his salary was increased by 12,000 maravedís. ${ }^{9}$ Only a few years earlier, in the winter of 1591, the cathedral's governing chapter had met to specify the duties of the maestro de capilla and to define details of the exacting examination that aspirants to the position would be required to satisfy. ${ }^{10}$ In Burgos, at the first hint that Bruceña might be tempted to seek employment elsewhere, the chapter met to convert the chapelmaster's prebend ad nutum amovible to a per-

\footnotetext{
7 Archival documents indiscriminately record his family name as 'Brizuela', 'Bruçeña', 'Bruzena', and 'Briceña', the latter being a variant favoured by some modern scholars. In the $A c$ tas capitulares of Burgos cathedral he is sometimes mistakenly referred to as Pedro de Bruceña, the result of an apparent lapsus calami. Our most thorough biographical sketch of Bruceña remains Luis Iglesias, "El maestro de capilla". See also Felipe Pedrell, "Bruceña, (Diego)", in Diccionario biográfico y bibliográfico de músicos y escritores de música españoles (Barcelona: Tip. de V. Berdós y Feliu, 1894-97), vol. 1, p. 228; José López-Calo, La música en la Catedral de Zamora (Zamora: Diputación de Zamora, 1985), pp. 273-277; Emilio Duro Peña, La música en la Catedral de Orense (Orense: Caixa Ourense, 1996), pp. 148-151; José López-Calo, "Diego Briceña" in Diccionario de la música española e hispanoamericana, 10 vols., ed. Emilio Casares Rodicio (Madrid: Sociedad General de Autores y Editores, 19992002), vol. 1, p. 696; and Francisco Javier Garbayo Montabes, Catálogo del archivo de música de la Catedral de Ourense (Santiago de Compostela: Instituto Galego das Artes Escénicas e Musicais, Xunta de Galicia, 2004), pp. xxxiii-xxxv.

${ }^{8}$ Dionisio Preciado, Alonso de Tejeda (ca. 1556-1628), polifonista español (Madrid: Editorial Alpuerto, 1974), vol. 1, p. 38, n. 82 .

9 Preciado, Alonso de Tejeda, vol. 1, p. 38, n. 86.

10 Preciado, Alonso de Tejeda, vol. 1, p. 34, n. 13 and p. 35, n. 19.
} 
manent position. ${ }^{11}$ Within months, the Capilla Real in Granada attempted to interest Bruceña in the vacancy created when Juan Martín Riscos left Granada for the cathedral of Jaén. The chapter in Burgos responded by offering Bruceña a salary bonus of 800 reales and in January 1603, the bonus was made permanent on condition that the chapelmaster remain in Burgos for a period of six years. ${ }^{12}$ This agreement seems to have been forgotten, however, when, on 1 April 1604, the chapter granted Bruceña leave so that he could join the contest for the coveted position of maestro at Toledo cathedral..$^{13}$ By 1606 , however, the Burgos chapter's mood had changed decisively: when Bruceña requested leave to contest the chapelmastership in Sigüenza, only five members of the chapter voted in favour while twenty-five voted against his petition. ${ }^{14}$ And on 3 March 1608 , the Burgos chapter dismissed Bruceña, unambiguously voicing its unalloyed disdain for his lack of loyalty. Five days later he was formally appointed maestro at Zamora cathedral. ${ }^{15}$ Among the Zamoran cathedral digni-

${ }_{11}$ AC Burgos cathedral RR 71 (20 May 1602), fols. 123v126. See López-Calo, La música en la Catedral de Burgos, vol. 4, pp. 30-32, document 1.573.

12 AC Burgos cathedral RR 71 (16 October 1602), fols. 250v-254. See López-Calo, Catedral de Burgos, vol. 4, pp. 42-48, documents $1.600,1.601,1.602,1.603$, and 1.612. See also AC Burgos cathedral RR 71 (13 January 1603), fol. 294v.

13 AC Burgos cathedral RR 71 (1 April 1604), fol. 522r. See López-Calo, Catedral de Burgos, vol. 4, p. 58, document 1.650 and AC Toledo cathedral (21 May 1604), vol. 23, fols. 182r-184r. The unusually detailed record of the expert musical skills that were expected from the contestants, and that is given in the Toledo AC, is examined in Philippe Canguilhem, "Singing upon the Book according to Vicente Lusitano", Early Music History, 30 (2011), pp. 55-103.

${ }^{14}$ Burgos cathedral RR 73 (1 September 1606), fols. 148. See López-Calo, La música en la Catedral de Burgos, vol. 4, p. 116, document 1.890 .

${ }^{15}$ Burgos cathedral RR 73 (3 March 1608), fol. 415. See López-Calo, Catedral de Burgos, vol. 4, p. 126, document 1.931: “...y resolvieron que atento que por el dicho Cabildo se han hecho muchas mercedes al dicho maestro de capilla en diferentes tiempos y él las ha reconocido muy mal, procurando salir desta santa iglesia y entrar en otras santas iglesias sin dar cuenta al Cabildo, y por otras justas causas que a ello les mueve[n], que se despida desde luego al dicho maestro de capilla y le han por despedido...". See Preciado, Alonso de Tejeda, vol. 1, p. 67, n. 47 for a transcription of AC Zamora cathedral vol. 1, fol. $65 \mathrm{r}$ (8 March 1608). taries who voted in favour of Bruceña's appointment was the cathedral's canónigo magistral Juan Pérez de la Serna (ca. 1566-1631) who later, as archbishop of Mexico, would play a key role in the 1624 tumult of Mexico and who, as Luis Iglesias discovered, was the dedicatee of the Bruceña choirbook. ${ }^{16}$ In the same year that Bruceña took up the reins at the head of Zamora cathedral's musical establishment, the cathedral took delivery of Sebastián de Vivanco's freshly-minted Liber Magnificarum (Salamanca: Taberniel, 1607), compensating the composer with the sum of 100 reales ${ }^{17}$ This book, with Pieter Perret's (15551637) superb signed engraving depicting the composer on its title page, must have made a profound impression on Bruceña, for, in the contract his representatives signed with Susana Muñoz in February 1620, Vivanco's book was specified as the model for his own polyphonic choirbook. ${ }^{18}$ It is perhaps not too speculative to imagine that

${ }^{16}$ See Angela Ballone, The 1624 tumult of Mexico in perspective (ca. 1620-1650) (Leiden: Brill, 2018); Francisco Javier Lorenzo Pinar and Luis Vasallo Toranzo, "D. Juan Pérez de la Serna, Arzobispo de México y Obispo de Zamora (ca. 15661631)", in Zamora y América. Actos de las Jornadas celebradas en Zamora los días 4, 5 y 6 de abril de 1991 (Zamora: Diputación Provincial de Zamora, Instituto de Estudios Zamoranos "Florián de Ocampo", 1992), pp. 523-37; Manuel Casado Arboniés, "Pérez de la Serna, Juan", in Diccionario biográfico español (Madrid: Real Academia de la Historia, 2009-2013), vol. 41, pp. 287-298, and Luis Iglesias, "El maestro de capilla", pp. 461-462.

${ }^{17}$ Archivo diocesano de Zamora (hereinafter ADZ), Libro de cuentas de fábrica [de la catedral] 1607-1623 (T. 112), fol. 14v: "Año de 1608: M[aestr]o de cap[ill]a de sal[aman]ca. descargansele cient Reales que por mandado del Cauildo se dieron al Maestro de capilla de Salamanca por un libro que ymbio de Magnificas de canto de Organo iijUcccc".

${ }^{18}$ In the final decade of the sixteenth century and the first decade of the seventeenth, Perret stood unrivalled in Spain in the art of copperplate engraving of illustrations and title pages for a variety of books. While he is perhaps most renowned for his engravings, produced between 1583 and 1589, of Juan de Herrera's (1530-1597) designs for Philip II's Escorial palace, he was also a skilled portraitist. Perret, like Tavernier, was born in Antwerp. In 1581, he moved to Rome before being called to Spain in 1583 by Herrera, who required superlative skills for his architectural engravings. In 1595 Perret was granted an annual subsidy of 100 ducats by Philip II and from 1597 he signed his work P. Perret Scalp[tor] Regis ("engraver to the King"). See Matilde López Serrano, "El grabador Pedro Perret", in El Escorial, 1563-1963. IV Centenario de la fundación del Monasterio 
Bruceña, impressed by the music typography of Artus Tavernier, Susana Muñoz's first husband, began laying early plans for the printing of his own polyphonic anthology. Indeed, it seems that Zamora, where he would remain until his death on 23 December 1622, offered the composer the kind of stability that would be conducive to a wellplanned compositional agenda.

Archival documents from Zamora cathedral attest to Bruceña's regular and successful negotiations for salary increases. And this time, in contrast to his behaviour in Burgos, Bruceña remained faithful to a commitment he made to remain in Zamora for the rest of his life. If this promise were tested in April 1612, however, when the cathedral of Santiago de Compostela and its archbishop Maximiliano de Austria sought to attract the composer to the post recently vacated by Periáñez, Bruceña successfully parlayed the offer to persuade the Zamora chapter to increase his salary and to provide him with a house. ${ }^{19}$

de San Lorenzo el Real (Madrid: Ediciones Patrimonio Nacional, 1963), vol. 2, pp. 689-716 and Luis Cervera Vera, Las Estampas de El Escorial por Juan de Herrera (Madrid: Editorial Tecnos, 1954) and Philip II and the Escorial: Technology and the Representation of Architecture, ed. Catherine Wilkinson Zerner, C. P. M. Brown et al (Providence, Rhode Island: Brown University, 1990).

19 AC Zamora cathedral, vol. 1, fol. 166r (12 December 1612): "Aumento de salario Al maestro de Capilla. En la ciudad de çamora Miercoles A doçe dias del mes de diçienbre de mill y seisçientos y doçe años los s[eño]res Dean y Cauildo de la sancta yg[lesi]a Catredal de la d[ic]ha ciudad estando juntos en su hordinario Cauildo en la Capilla de Santiago como lo tienen de uso y costunbre es A sauer don Martin do canpo subdean Canonigo don bernardino de ledesma Arcediano de zamora Canonigo don fran[cis]co Arias Pichardo thesorero y Canonigo doctor baltasar Rodriguez. Antonio bermudez xpoual de salamanca Pablo enrriquez Geronimo de la Torre don Gaspar Prieto de Aldana Arcediano de Toro Canonigo don Pedro de Monrroy Mastrescuela Canonigo don lorençio Moran Prior Canonigo don $\mathrm{Al}[$ ons]o Rodriguez de la Cueva. Abad de San espiritus Canonigo doctor Juan fernandez de Valdiuieso Nicolas Gomez de Aguero doctor fran[cis]co de Aguilar Doctor don Gaspar de Matienço don diego ordoñez y don fernando de fig[uero]a Todos Canonigos Prebendados de la d[ic] ha sancta ygl[esi] a que fueron llamados Para el ynfraescrito negocio Por Antio de florez su pertiguero que de ello dio fee los d[ic] hos s[eño]res subdean y Tesorero hiçieron Relación Al dicho Cauildo Como por su mandado. Auian ablado al s[eño]r diego de bruçena Racionero y Maestro de Capilla de la d[ic]ha sancta ygl[esi]a sobre sauer su yntento porque se queria yr a la de sanctiago de donde le auian llamado y que auian entendido del que si le
In addition to offering precise dates and other details of Bruceña's employment, the AC of the cathedrals in which he served reveal the chapelmaster to have been a decidedly quarrelsome character. As early as 1591 the chapter of Orense cathedral had received complaints about Bruceña's behaviour that were too salacious to be put into writing and in 1592 he and a prebendary named Pascual engaged in a bloody altercation in which Pascual called Bruceña a "shameless, rapacious villain" ("rapaz, vellaco, desvergonzado") to which Bruceña responded: "Rogue Jew, who on seeing St Peter chop off Malcho's ear would, like a Jew, have hacked off the other ear" ("judío vellaco, que de la manera que sant Pedro había sacado la oreja a Malchus, él como a judío se le había de sacar otra"). ${ }^{20}$ In 1604, in Burgos, the prosecutor Damián Bueno denounced Bruceña and the tiple Alonso de Tobar for a violent altercation in the Convento de la Merced, in a case that was still being pursued before the courts fourteen years later. ${ }^{21}$ In 1605 , the same prosecutor accused Bruceña and an accomplice - his housemaid - of having seduced a number of women. ${ }^{22}$ And in Zamora, in December 1611, the entire band of recently dismissed cathedral minstrels visited Bruceña's house where insults were angrily traded and Bruceña's life was threatened..$^{23}$

Aumentauan veintemill marauedis de salario perpetuos Como lo demas tenia y le dauan Casa en que Uiuiese de Ual de se quedaria a seruir en esta sancta ygl[esi]a en el d[ic]ho su officio Como [h] asta aqui sobre lo qual los $\mathrm{d}[\mathrm{ic}]$ hos $\mathrm{s}$ [eñor]es difirieron $\mathrm{y}$ trataron y mandaron se bote secreto sobre si le an de Acrecentar o no el d[ic]ho salario y Auiendolo botado Con Abas blancas y negras que por las blancas se entiende que se le aumente y por las negras que no salio por mayor parte de Uotos que se le Aumente el dicho salario y hunanimes y Conformes. Acordaron que se le den seisçientos Reales de Aumento de salario cada año mas del que [h] asta aqui [h] a tenido y en la mesma forma que lo demas de los bienes y rentas de la fabrica desta dicha sancta yglesia y lo mandaron Poner por acuerdo y lo firmo el d[ic]ho s[eño]r subdean e yo el presente notario de que doy fee."

${ }^{20}$ Duro Peña, La música en la Catedral de Orense, p. 149, and Luis Iglesias, "El maestro de capilla", p. 436.

${ }^{21}$ Burgos cathedral archive LIB-82, fols. 921-935 (1604), fol. 1090 (1618) and fol. 1098 (1618).

22 Burgos cathedral archive LIB-82, fols. 960-999 (1605).

23 AC Zamora cathedral, vol. 1, fols. 146v-147r: "menestriles despedidos. Miercoles A 14 de diciem[br]e de seisçientos y onçe los s[eñore]s Presidente y cab[ild]o de la s[an]ta yglesia de çam[or]a juntos en su cab[ild]o ordinario Como es Costumbre es a sauer Don gaspar prieto de Aldana Ar[cedia]no de Toro y cano- 

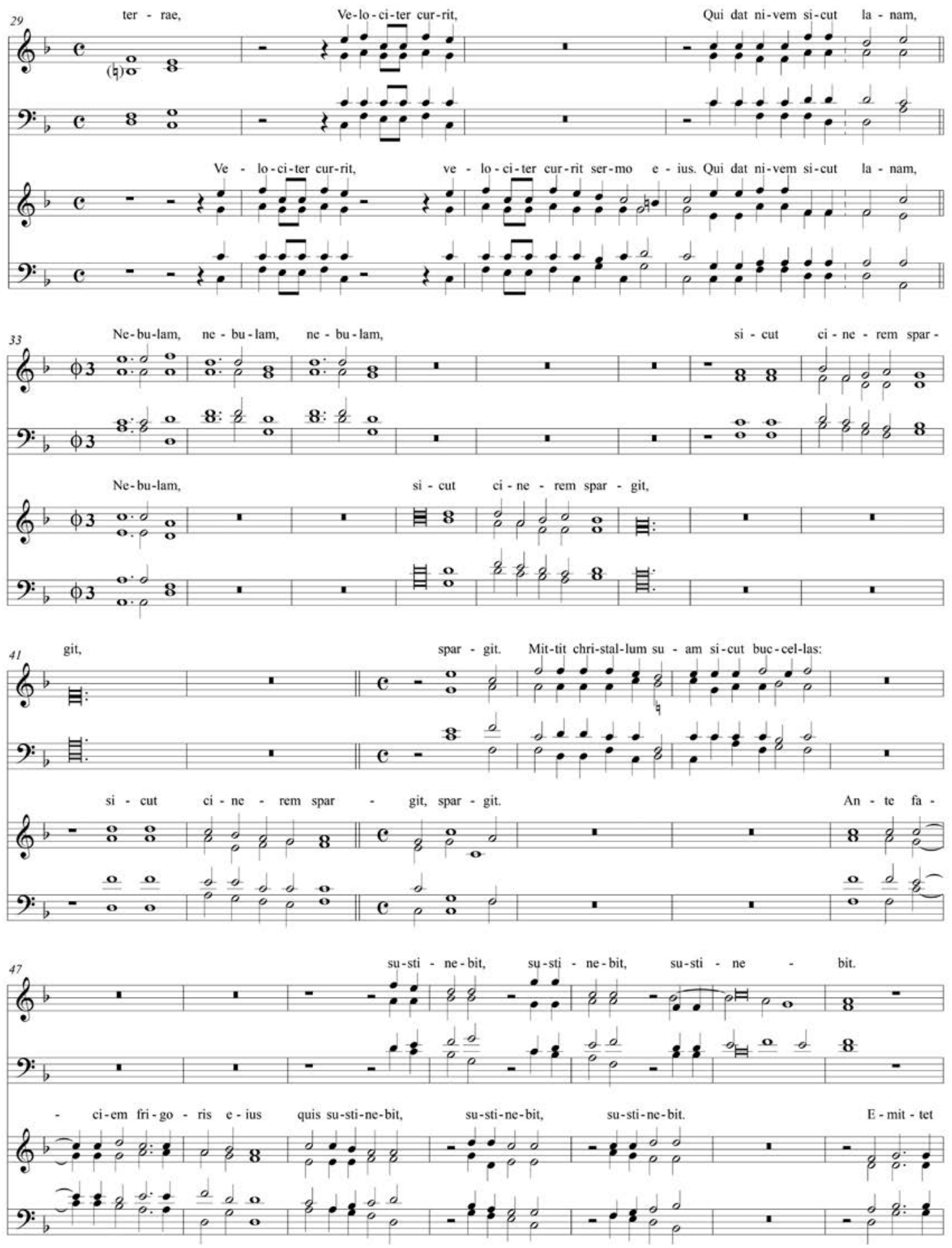

Example 1. Diego de Bruceña, Lauda Jerusalem (8vv), bb. 29-53. 
Lamenting what they understood to be the loss of all exemplars of Bruceña's book of polyphony, both López-Calo and Luis Iglesias cited the two works of Bruceña's that were known to have survived: a Lauda Jerusalem 8vv (see Music Example 1) and a De profundis $8 \mathrm{vv} .{ }^{24}$ And while we know that Bruceña composed "una comedia para la noche de navidad" in Ourense and villancicos for all the cathedrals he served, none of these works is known to survive..$^{25}$

nigo Don $\mathrm{P}[\mathrm{edr}]$ o de monroy maestresq[uel]a y can[onig]o con el voto del $\mathrm{D}[\mathrm{oct}]$ or $\mathrm{Di}[\mathrm{eg}]$ o del val nicolas gomez con el voto del $\mathrm{D}$ [oct]or serna Don di[eg]o ordonez con el voto del Dean Don fran[cis]co Arias Pichardo Ant[oni]o Bermudez Don martin do campo christoual De Salamanca Paulo enrrique canonigos prebendados de la dicha s[an]ta yglesia, Dijeron que por quanto Vino a notiçia del cab[ild]o que los menestriles desta s[an]ta yglesia fueron este dia passado a casa del maestro de capilla y le dijeron muy malas palabras y le quisieron matar lo qual consto por rrelacion del dicho maestro de cap[ill]a y por la que algunos $\mathrm{s}$ [eñore]s capitulares hiçieron en esta Raçon por lo qual acordaron que se despidiesen y los ubieron por despedidos y mandaron se notifique a gabriel De fuentes Teniente de fabriquero les aya por despedidos y no les acuda con marauedis algunos ni trigo, e yo el dicho secretario en cumplim[ien]to del dicho Acuerdo lo notifique al dicho Theniente de fabriquero y lo firmo el s[eño]r Presidente y mandaron que solo quede a seruir Manuel fernandez Vajon. Ante mi [signed:] Don diego de Ledesma s[ecretari]o. “

${ }^{24}$ A facsimile of one page of Bruceña's Lauda Jerusalem 8vv (Zamora cathedral Música 11/14) is reproduced in Civitas: Exposición organizada con motivo del 1100 aniversario de la restauración de la ciudad de Zamora (Zamora: Junta de Castilla y León, 1993), p. 162. In addition, the following works by Bruceña were listed in the Primeira parte do index da Livraria de musica do muyto alto e poderoso Rey Dom Ioão ó IV. Nosso Senhor (Lisbon: Paulo Craesbeek, 1649): Ah del alma (dúo y a $6 \mathrm{vv}$ ), El que piensa que le dan (diálogo, a 12vv), En invierno nacen las flores (a $3 \mathrm{vv}$ y a $8 \mathrm{vv}$ ), Qué abrasado de amores (a $3 \mathrm{vv}$ y a $4 \mathrm{vv}$ ) and a Responde mihi 6vv. See Luis Iglesias, "El maestro de capilla", p. 459, and Alejandro Luis Iglesias, La colección de villancicos de João IV, rey de Portugal (Mérida: Editora regional de Extremadura, 2002), vol. 1, p. 212 (Nos. 1240 and 1244), p. 214 (No. 1275), and p. 224 (No. 1453).

25 See Duro Peña, La música en la Catedral de Orense, pp. 149-150. Payments to Bruceña for his composition of villancicos are recorded in ADZ, Libro de cuentas de fábrica [de la catedral] 1607-1623 (T. 112), fol. 121r (200 reales for villancicos composed for Christmas, Corpus Christi, and its octave in 1613.), fol. 174r (ditto, 1614), and fol. 227r (13,600 maravedis for villancicos composed in 1617).
From its Libro de cuentas de fábrica 1607-1623 we know that Zamora cathedral purchased, in addition to Vivanco's Liber magnificarum (1607), copies of Vivanco's book of masses (1608), all three of Esquivel's polyphonic choirbooks (1608 and 1613) and, in 1620, Bruceña's own book of polyphony. ${ }^{26}$ There can be no doubt that Bruceña was thoroughly familiar with the choirbooks printed by the firm founded by Tavernier and Susana Muñoz, and it was to her that Bruceña turned when in 1620 he was ready to see a book of his own through the press.

\section{SUSANA MUÑOZ (FL. CA. 1580-CA. 1625), "YMPRESSORA DE LOS LIBROS DE MÚSICA"}

The earliest record thus far uncovered concerning Susana Muñoz is found in a baptismal register from Salamanca cathedral. ${ }^{27}$ On 18 March 1589 Susana Muñoz and her husband Artus Tavernier (described as a 'fundidor de letras') appeared as godparents at the baptism of a daughter of the printer Juan del Campo and his wife Ana de Amberes. ${ }^{28}$ Susana was the daughter of Pedro Muñoz and Catalina Hernández; she bore five daughters - Antonia (b. 1589), Susana (b. 1591), Teresa (b. 1596), Isabel (b. 1598), and Amaya (b. 1605) - and one son, Jacinto

26 ADZ, Libro de cuentas de fábrica [de la catedral] 16071623 (T. 112), fols. 14v, 42v, and 312v.

27 On Susana Muñoz, see Luisa Cuesta Gutiérrez, La imprenta en Salamanca. Avance al estudio de la tipografía salmantina (1480-1944) (Salamanca: Diputación Provincial de Salamanca, 1960), p. 59; Juan Delgado Casado, Diccionario de impresores españoles: (siglos XV-XVII) (Madrid: Arco Libros, 1996), vol. 2, pp. 478-79; Albert Corbeto, "Las musas ignoradas", pp. 27-28; Sandra Establés Susán, Diccionario de mujeres impresoras y libreras de España e Iberoamérica entre los siglos XV y XVIII (Zaragoza: Prensas de la Universidad de Zaragoza, 2018).

${ }^{28}$ Archivo Diocesano de Salamanca (hereinafter ADSA), 438/1 (Libro parroquial de bautizados de la s[an]ta Iglesia Catedral de Salamanca, núm 1), fol. 22v (18 March 1589). See Vicente Bécares Botas, Guía documental del mundo del libro salmantino del siglo XVI (Segovia: Fundación Instituto Castellano y Leonés de la Lengua, 2006), p. 91; and Yolanda Portal Monge and María Paz de Sena Espinel, "Artistas y artesanos del libro en la Salamanca del XVI a través de los libros parroquiales de bautismo", Memoria Ecclesiae, 9 (1996), pp. 221-257, p. 254. On Artus Tavernier, see Cuesta Gutiérrez, La imprenta en Salamanca, pp. 53-55 and Bécares Botas, Avance para una guía p. 130. 
$(\dagger 1641) .{ }^{29}$ In about 1621 , the latter would inherit the printing house that Susana was to build in consecutive partnerships with her three husbands. The earliest records documenting the presence in Salamanca of Susana's first husband, the Antwerp-born Tavernier, are from 1588. On 29 June 1588, 'Artus impresor vecino desta ciudad' is cited as one of the witnesses at the marriage of Martin de Verbis and Maria López. ${ }^{30}$ Two days later (on 1 July 1588) Artus, described as 'flamenco fundidor de letras', is documented in a notarised letter of intent ('carta de obligación') in which he agrees to purchase 'libros e otras cosas' from a Parisian bookseller. ${ }^{31}$ As the son or nephew of the celebrated punchcutter, type-founder, and printer Ameet Tavernier (ca. 1522-1570), Artus had grown up in Antwerp surrounded by some of the most celebrated exponents of the printing trade. ${ }^{32}$ And while Artus himself had already printed at least one music book - the Premier Livre des Hymnes anciens, mis en vers françois, par Ch. de Navières (Antwerp, 1580) ${ }^{33}$ - his occupation is more commonly given in archival records of the 1590s as 'fundidor de letras' rather than 'impresor'.

As soon after his arrival in Salamanca as 24 January 1591, Artus busied himself founding type for the printer Miguel Serrano de Vargas and his wife María de Urueña. ${ }^{34}$ It was during the last decade of the century that Artus must have made the decision to found his own press in Salamanca. On 27 December 1602, we find him in Madrid signing a bill of sale in which he agreed to pay 572 reales, the balance that he owed for the total cost of two printing presses and 25.5 arrobas (about 288 kilograms) of metal type, all purchased from a Cristóbal de Contreras acting on behalf of the printers Luis and Francisco Sánchez. ${ }^{35}$ Like so many of his expatriate compatriots in

29 ADSA 417-9, fol. 124v (2 July 1620).

30 ADSA 417-9, fol. 50v (29 June 1588).

31 Archivo Histórico Provincial de Salamanca (hereinafter AHPSA), Protocolos Notariales, 2952 (1588), fol. 444.

${ }^{32}$ Mike Parker, K. Melis and Hendrick D. L. Vervliet, "Typographica Plantiniana III. Ameet Tavernier. Punchcutter (ca. 1522-1570)", De Gulden Passer, 39 (1961), pp. 17-76, and Maurits Sabbe, Ameet Tavernier (Nijhoff, 1923).

${ }^{33}$ The unique extant exemplar is held at GB-Lbl under the class mark Music Collections Hirsch III.953.

${ }^{34}$ AHPSA PN 4651, fol. 354. See Bécares Botas, Guía, p. 253.

35 Archivo Histórico de Protocolos de Madrid, Protocolos Notariales 2173, fol. 836. See Don W. Cruickshank, "Some as-
Salamanca, Artus adopted a Castilianised form of his surname and in 1604 he began using a printer's device incorporating an anagram of his name: 'ARTE NATVS LIBER'. In the seven years between 1602 and his death, which occurred some time before 24 July 1609 , Tavernier printed more than 50 titles, six of which contained music, and four of which were large format choirbooks. ${ }^{36}$ The 14 months between July 1607 and September 1608 represented an especially intense period for the press, for in this period it produced no fewer than four luxury polyphonic choirbooks, accounting for a total of more than 1,000 pages of printed polyphony. ${ }^{37}$ Only twelve days before the fourth of these - Vivanco's mass book - was completed, Artus and Susana are found, on 12 September 1608 , investing the considerable sum of 8,680 reales in four presses and a variety of printing supplies. The purchase of these goods from the printer Andrés Renaut in Salamanca is documented in a bill of sale that is important for several reasons ${ }^{38}$ First, it is the earliest notarial document thus far uncovered in which Artus and Susana are listed as equal partners and in which the couple is described as 'ynpresores e mercaderes de libros'. Second, the purchase includes metal type for music as well as text and, third, it shows us that Susana was illiterate, the document being signed on her behalf by a witness. Given the considerable sum involved, it seems possible that the music type might have been lent to Tavernier by Renaut for use in the production of the four polyphonic choirbooks that were printed in 1607 and 1608 , all of which use the

pects of Spanish book-production in the Golden Age", The Library, 5/1 31 (1976), p. 7.

${ }^{36}$ Concerning the date of Tavernier's death, see Dámaso García Fraile, Sebastián de Vivanco (c. 1550-1622): Libro de motetes (1610). Estudio y transcripción, 2 vols. (Salamanca: Fundación Las Edades del Hombre, 2001-2002).

${ }^{37}$ If the dates given in the colophons of these four choirbooks are to be understood as literal and precise, then the book of Vivanco's magnificats was completed on 31 July 1607, the book of Esquivel's masses was completed on 14 February 1608, the book of Esquivel's motets was completed on 27 June 1608, and the book of Vivanco's masses was completed on 24 September 1608 .

38 AHPSA PN 3243, fols. 159-162 (12 September 1608). On the brothers Juan and Andrés Renaut, see Lorenzo Ruiz Fidalgo, La imprenta en Salamanca (1501-1600) (Madrid: Arco Libros, 1994), vol. 1, pp. 122-125, and Bécares Botas, Guía, pp. 230233. 
music type that was to define the house style of the firm's polyphonic choirbooks. The fact that four non-music titles printed by Tavernier between 1606 and 1608 were printed in cooperation with Antonia Ramírez, Andrés Renaut's widow, offers further evidence of the kind of close working relationships were typical in Salamanca's thriving printing community. ${ }^{39}$

We do not know if the couple's substantial investment in printing supplies was motivated by any presentiment of Artus's death. What is clear, though, is that in 1609 Susana faced a crisis: by 24 July 1609, Artus would be dead and she would be held responsible for the considerable debt that they must have incurred in the previous year. At the end of 1609, the first volume to emerge under Susana's name, albeit in the familiar formulation 'widow of', was printed: Luis de Miranda, Exposicion de la regla de los hermanos terceros, assi seglares, como religiosos, comunmente llamados de la penitencia (Salamanca, Por la viuda de Artus Taberniel, 1609). ${ }^{40}$

Little is known about Francisco de Cea Tesa, the printer whom Susana Muñoz married in late 1609 or $1610 .^{41}$ In the period 1610 to 1613 Cea Tesa printed 20 volumes, two of which occupy important positions in Spanish music history. The first, issued in 1610, was Montanos's Arte de canto llano and the second, produced

39 Pedro de la Vega, Declaracion de los siete psalmos penitenciales, primera parte (Salamanca: en la imprenta de Artus Taberniel a costa de Antonio Enríquez, 1606); Francisco Zumel, Tous variarum disputationum tam ad primam partem ad primam secundae sancti Thomae (Salamanca: excudebat Artus Taberniel et Antonia Ramírez, 1607); Antonio Pichardo Vinuesa, In tres priores institutionum imperatoris Iustiniani libros commentarii in quibus omnes fere iuris civilis \& regii quaestiones disputantur \& definiuntur quos idem auctor secundum recensuit, auxit duplici adiecto indice (Salamanca: apud Artus Taberniel et Antonia Ramírez expensis autor, 1608) and Francisco Zumel, Opuscula libros III. Ad primam partem et ad primam secundae duos variarumque quaestio num alium continentia s. Ildefonsus de Monroy dicat et consecrat (Salamanca: Antonia Ramírez et Artus Taberniel, 1608).

40 The fact that its dedicatory letter is dated 17 October 1609 , allows us to conclude that the volume was printed at the end of 1609 .

${ }^{41}$ On Francisco de Cea Tesa, see Cuesta Gutiérrez, La imprenta en Salamanca, pp. 57-58; Delgado Casado, Diccionario de impresores españoles, vol. 1, p. 136; and José María de Valdenebro y Cisneros, La imprenta en Córdoba. Ensayo bibliográfico (Madrid: Sucesores de Rivadeneyra, 1900), p. xviii. in 1613 with a page count of almost 600, stands as the largest choirbook ever printed in the peninsula: the Psalmorvm, Hymnorvm, Magnificarvm...Tomvs Secvndvs of Juan Esquivel de Barahona. Despite the fact that he proclaimed himself 'Cordubensis' in both title pages and colophons, Francisco was not part of the celebrated Cea Tesa printing dynasty that flourished in Córboba in the period 1588-1703. That Francisco died some time between 25 February 1613, the date given in the colophon to Esquivel's Psalmorum, Hymnorum, and 9 June 1613 can be confirmed by reference to a contract for the printing of a book of motets on the latter date. The parties to the contract were Sebastián de Vivanco and Susana Muñoz who is described, on that date, as 'widow of Artus Taberniel and Francisco de Cea Tesa'. ${ }^{2}$ The colophon in Vivanco's book of motets gives its printer as 'viudam Francisci de Cea Tesa' and from 1613 until 1620 at least 29 books were issued under her imprint. ${ }^{43}$ Early in 1620 , she would sign a contract with Diego de Bruceña for the printing of the book that is the subject of this article yet the name on its title page would be that of the man she married on 2 July 1620 , the printer Antonio Vázquez.

Table 1 lists the eleven music books that were printed by Susana Muñoz or one or other of her three husbands (Artus Tavernier, Francisco de Cea Tesa, and Antonio Vázquez) in the period 1580 to 1620 . The simple fact that ten of these books were printed in Salamanca in a fourteen-year period (1606-1620) is one that remains unrecognised in Spanish music historiography. The phenome-

${ }^{42}$ AHPSA PN 3.752, fols. 310r-313v (9 June 1613): 'viuda muger que fue de Artus Taberniel y de Fran[cis] ${ }^{\text {co }}$ de Çea [Tesa Córdoba] sus maridos difuntos veçinos que fueron de la d[ic]ha çiudad.'

43 The title of Vivanco's motet book [RISM V 2251] is unknown, since none of the four extant copies preserves the title page. Until Javier Marín's recent discovery in Mexico City Cathedral of the only exemplar with its colophon intact, the publication date of the book of motets was universally, but erroneously, accepted as 1610. Since the colophon date of 1614 is consistent with the date of the printing contract, there is no reason to doubt 1614 as the date of printing and any suggestion that there were two editions must be rejected. See Javier Marín López, "Cinco nuevos libros de polifonía en la Catedral Metropolitana de México", Historia Mexicana, 52/4 (2003), pp. 1073-94. The name Susana Muñoz appears on the title pages of at least 23 volumes; in two others, the printer's name is given in some such formulation as 'Susana Muñoz viuda', and in four others as 'viuda de Francisco de Cea Tesa'. 
non has been ignored by historians of the book and the fact that the thread connecting the books, and many other non-music imprints, was an illiterate woman from Salamanca has gone unrecognized.

\section{DIEGO BRUCEÑA'S “LIBRO DE CANTO DE MISAS Y MAGNIFICAS Y MOTETES Y UNA SALUE"}

Thanks to Luis Iglesias's discovery of some key archival documents, and his painstaking analysis of those documents, we know a good deal about the genesis of Diego de Bruceña's book of polyphony. ${ }^{44}$ Luis Iglesias has shown that on 23 February 1620, Diego de Bruceña signed a power of attorney ('carta de poder') authorising Marcos Crespo and Juan Concejo de León to act on his behalf in negotiating an agreement with Susana Muñoz for the printing of "un libro de mussica magnificas motetes y missas". Concejo de León was a priest and capellán de número of Zamora cathedral and the licenciado Marcos Crespo was a prebendary ('racionero') of Salamanca cathedral. On 26 February 1620, in Salamanca, Crespo and Concejo de León, acting as Bruceña's legal representatives, met with Susana Muñoz to sign a formal contract ('publica escriptura de asiento') that specified the precise terms under which Bruceña's book would be printed. At the same time, they delivered into her hands a specially prepared manuscript containing 'six masses, eight magnificats and fourteen motetes, labeled at the beginning' ${ }^{45}$ The contract stipulated a printrun of forty copies, that the work would begin on 9 March 1620 , and that it would keep the press busy for 75 days without a break ('y no le dejar de la mano'), the work thus being completed by the end of May. In the event that Muñoz failed to comply with this work schedule, she would incur a penalty of 50 ducados. The printer assumed responsibil-

\footnotetext{
44 The archival documents include a 'Poder del Raz[ioner]o di[eg]o brizuela' (8 November 1617) Archivo Histórico Provincial de Zamora (hereinafter AHPZ), protocolo de Francisco Martínez de la Torre, año 1617, sign. 637, fol. 809, a 'Poder de Diego de Bruzeña' (23 February 1620), AHPZ Protocolo de Pedro de Salamanca, año 1620, sig. 764 fols. 69-70, a 'contrato de impresión' (26 February 1620) AHPSA PN 2973, fols. 1141r-1444r, and a 'Testamento diego de bruçena maestro de capilla' (16 December 1622), AHPZ protocolo de Pedro de Astorga, año 1622, sign. 850, fols. 723r-729.

45 AHPSA PN 2973, fol. 1141v.
}

ity for proof reading and undertook to ensure that folios were proof read as they emerged, one by one, from the press. Additionally, the printer was responsible for errors that remained uncorrected after proof reading and she would be responsible for the cost of all materials including paper. As Luis Iglesias points out, a clause in Bruceña's last will and testament seems to confirm that Juan Pérez de la Serna, the seventh archbishop of Mexico (1613-1627) and bishop of Zamora (1627-1631), had provided the sum of 2,000 reales to cover the costs associated with the printing of the volume. ${ }^{46}$

\section{THE BRUCEÑA CHOIRBOOK: BIBLIOGRAPHICAL DESCRIPTION}

The unique exemplar preserved today in the cathedral of Miranda do Douro is incomplete. In addition to its missing slightly more than a third of its pages, the book has suffered damage caused by routine use, as well as mold and humidity on both its covers and its pages. ${ }^{47}$ Many of the pages have been torn and creased and paper pasteovers have often been inexpertly deployed to repair damaged pages. We know, from an entry in an inventory of 1675 from Cuenca Cathedral, that the volume originally comprised $299(=300)$ pages in 25 gatherings of six folios (= three pliegos) $)^{48}$ The pages, described in the

${ }^{46}$ Luis Iglesias, "El maestro de capilla", p. 456. See AHPZ protocolo 850 , fol. 726v (16 December 1622): “yten digo que el $\mathrm{s}$ [eño]r arcobispo de mexico a quien dirigi un libro de musica y presente ciertos cargos de el me tiene su illustrisima prometida alguna cantidad de dineros para ayuda la costa que tube en la impresion de dicho livro..." and fol. 727r: "otrosi digo quel dicho $\mathrm{s}[\mathrm{eño}] \mathrm{r}$ arçobispo de mexico me yço merced de me inviar [h] abra seis u siete años dos mil Reales y para la cobrança dellos di poder a melchor garcía cura que al presente es del perdigón y dixeron [h] aber se perdido digo que si en algun tienpo ubiere claridad alguna para los poder cobrar es mi boluntad se agregen al demas Resto de [h]acienda para la memoria contenida y en cargo a mis testamentarios [h] agan diligencia en la cobrança dellos paso el poder ante fr[a]ncisco martin escribano ya difunto."

47 The following 106 pages are entirely, or in one or two cases almost entirely, lacking: 1-86, 89-90, 173-176, 191-196, 293-300. There are three errors in the volume's Arabic-numeral pagination: 221 recte 223, 227 recte 229, and 281 recte 283 .

48 "Ytten otro Libro de Brizeña de 299 foxas Con 6 misas y 8. Magnificas y 16 motetes." See José Luis de la Fuente Charfolé, "Inventarium librorum musicae: nueva aportación documental sobre el archivo musical de la catedral de Cuenca (siglos 
printing contract as 'de marca mayor', now measure 550 $\mathrm{mm}$ x $420 \mathrm{~mm}$, having been cropped before binding. The first folio to survive intact is 91-92. Of the title page, only the lower inside quadrant remains, still attached to the binding (see Illustration 1); it is followed by pp. 87-88. There are two loose detached fragments of printed pages. ${ }^{49}$ The binding, which appears to be original, consists of wooden boards covered with brown leather that is lightly tooled with a series of concentric rectangles. The edges of the binding boards were originally reinforced with narrow tin strips, some of which are now missing. Both covers measure $575 \mathrm{~mm}$ x $435 \mathrm{~mm}$ and are furnished with four decorative brass cornerpieces and one brass centerpiece. The remnants of two clasps that might have been of either leather or brass are visible. A single blank paper guard sheet is pasted to the inside front cover and the remains of a similar guard sheet are attached to the inside back cover.

The documentary record does not tell us who was responsible for the day to day decisions that were made in the production of the book. While much was specified in the escritura, or printing contract, that was signed by Bruceña's representative and Susana Muñoz on 26 February 1620, the book's title page bears the name of Antonio Vázquez, the printer to whom Susana was formally bethrothed on 2 July $1620 .{ }^{50}$ For the moment, we can assume that the labour was shared between husband and wife and it is certainly the case that as late as 1625 Vázquez and Muñoz were signing print-

XVII-XVIII)", Anuario Musical, 62 (2007),p. 185. That the book comprised 150 sheets ( $=300$ numbered pages) is confirmed by the printing contract's stipulation that the printing would take 75 days at the rate of two pliegos per day, see AHPSA PN 2973, fol. 1141r: "Yten que [h] a de comencar a ymprimir el dicho libro desde nueue dias del mes de março benidero deste presente año y no le dejar de la mano y a de dar ynpresos cada dia de trabajo dos pliegos de forma que dentro de setenta y cinco dias de trabajo que corren desde el dicho dia nueue de marco deste año [h]a de dar acauado de ymprimir el dicho libro en la dicha forma." Signature marks appear at the bottom recto of each folio in alphabetical order (omitting the letters $\mathrm{J}, \mathrm{V}$ and $\mathrm{W}$ ) followed by ' $\mathrm{Aa}$ ' and ' $\mathrm{Bb}$ '.

49 One fragment comprises the upper outside quadrant of pp. 87-88; it preserves most of the Altus, a fragment of the Bassus, some of the Superius, and a small section of the Tenor. The other fragment is a small section of the outer side of the lower quadrant of pp. [89]-[90]; it preserves seven notes from the Bassus of the Sanctus and about fourteen notes and a rest of the Tenor of the Benedictus of Bruceña's Missa Elisabeth Zachariae.

50 ADSA 417-9, fol. 124v (2 July 1620).

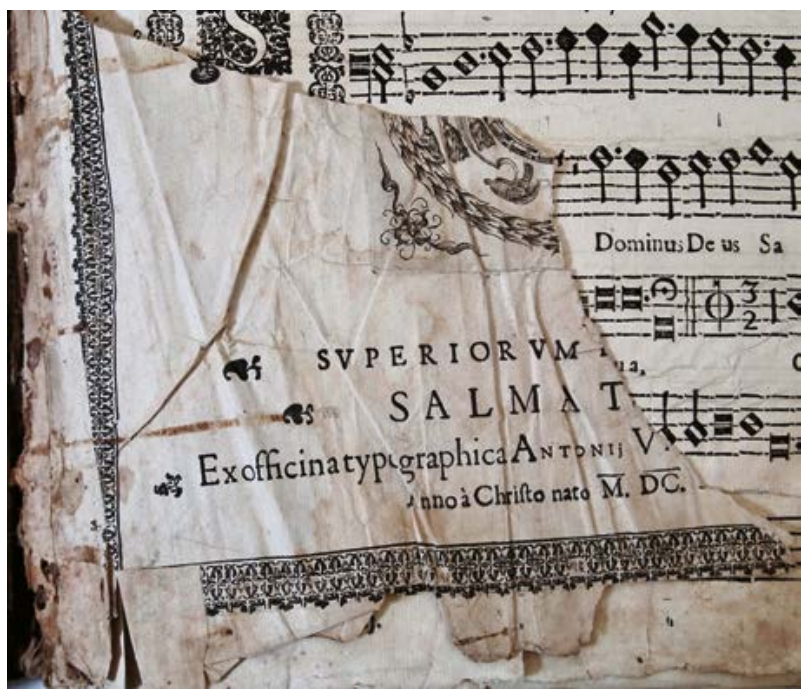

Illustration 1. Bruceña choirbook, title page.

ing contracts as a married couple..$^{51}$ The escritura of 1620 clearly states that Bruceña's book was to be modelled on 'the book of maestro Vivanco'. ${ }^{52}$ Although three books of Vivanco's music had been printed by Susana Muñoz and her first husband Artus Tavernier, it is clear that the Liber magnificarum (1607) was the model for the six subsequent choirbooks. It is no surprise, therefore, to find that the title page of Bruceña's book, most of which is now lost, shares distinctive typographical and layout characteristics with Vivanco's maiden print.

In designing the title page of the Bruceña choirbook (see Illustration 1), Muñoz (and possibly Vázquez) modelled their layout on the title page of Vivanco's Liber magnificarum with one notable difference: they chose to encase the title page's text and central copperplate engraving within a decorative border. ${ }^{53}$ It was, in fact, the same border employed in two books printed by Francisco

${ }^{51}$ AHPSA PN 2978, fols. 1198r-1203r (25 May 1625).

52 AHPSA PN 2973, fol. 1141r: "Primeramente en que yo el dicho juan concejo en el dicho nombre doy a ymprimir a la dicha susaña muñoz vn libro de canto de misas y magnificas y motetes y una salue compuesto por el dicho mi parte el qual ha de ymprimir de la forma siguiente. Primeramente que ha de ser impresso en la forma que ymprimio el libro del maestro beuanco en el propio punto y las propias pautas y papel y regla".

${ }^{53}$ For a facsimile of the title page of Vivanco's book of magnificats, see Michael Noone and Graeme Skinner, eds., Se- 
de Cea Tesa, Susana's second husband, in books he printed in 1610 and 1611 respectively. ${ }^{54}$ The border comprises a number of modular ornaments that are found in many configurations in many books printed by the firm and it is clear that the same metal type was used in different configurations, for different decorative purposes, in many different titles. Illustration 2 shows two of the modular ornaments, joined to give the impression of a single ornament, as they appear in Manrique's Meditaciones para los días de Quaresma and Illustration 3 shows them in combination with another ornament. ${ }^{55}$
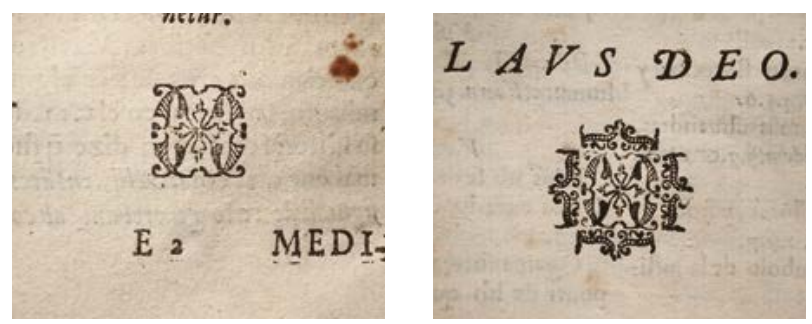

Illustrations 2 and 3. Modular ornaments from Ángel Manrique, Meditaciones para los días de Quaresma (Salamanca: Francisco de Cea Tesa, 1612), pp. 67 and unnumbered page before colophon.

In her printing of Nicolás Bravo's Vigilia magna (1616), Susana Muñoz used the same ornaments to mark the beginnings of chapters (see Illustration 4).

bastián de Vivanco: Liber Magnificarum (1607) (Middleton, Wisconsin: A-R Editions, 2020), plate 1.

${ }^{54}$ Francisco de Montanos, Arte de canto llano, con entonaciones comunes de coro, $y$ altar, y otras cosas (Salamanca: en casa de Francisco de Cea Tesa, a costa de Andrés López, mercader de libros, 1610) <http://bdh-rd.bne.es/viewer.vm?id=0000110645 \&page $=1>$ and Juan Alfonso de Curiel, Controversiarum, libri duo (Salamanca: Diego de Cossío and Francisco de Cea Tesa, 1611) <https://babel .hathitrust.org/cgi/pt?id=ucm.5317977484\&v iew $=1$ up\&seq $=5>$. In Montanos's Arte de canto llano, the border is used to surround an illustration of the Guidonian hand on fol. 4r$4 \mathrm{v}$ and in the Curiel volume it appears on the title page. The same decorative border was used to divide the two columns of the index page of Esquivel's Psalmorvm (1613); for a facsimile of which, see Robert J. Snow, The 1613 Print of Juan Esquivel Barahona (Detroit: Detroit Monographs in Musicology, 1978), p. 15.

55 Ángel Manrique, Meditaciones para los días de Quaresma, sacadas de los Evangelios que canta en ellos la Iglesia, nuestra Madre (Salamanca: Francisco de Cea Tesa, 1612).

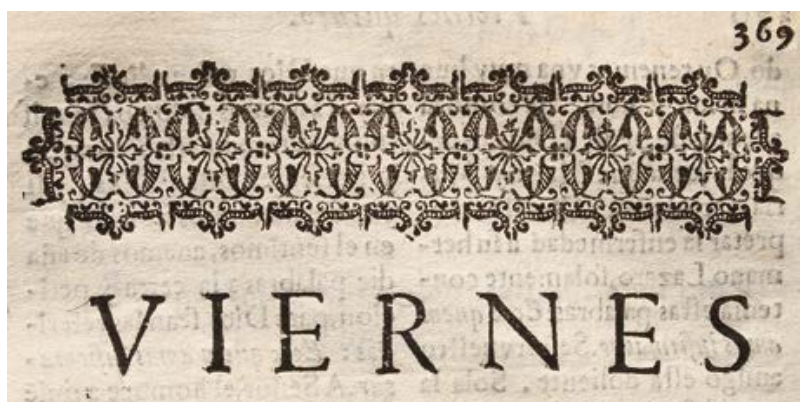

Illustration 4. Modular ornaments from Nicolás Bravo, Vigilia magna de Christo (Salamanca: Susana Muñoz, 1616), p. 369.
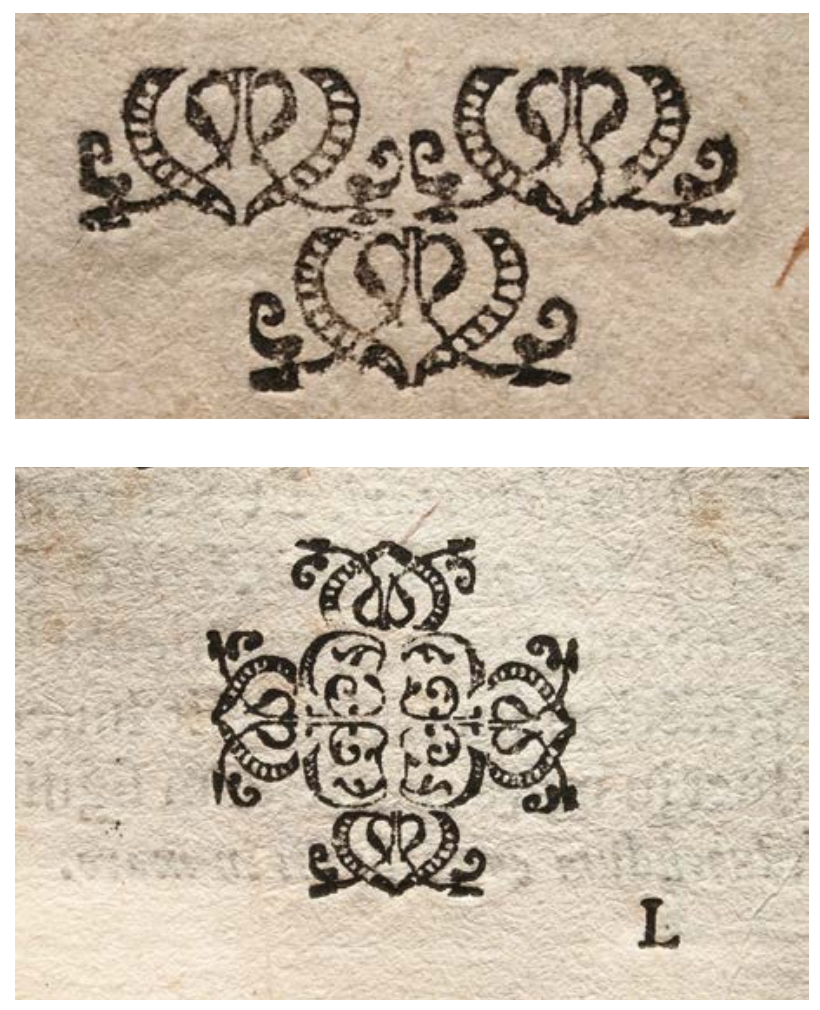

Illustrations 5 and 6. Modular ornaments from Juan de Solórzano Pereira, De parricidii crimine disputatio (Salamanca: excudebat Artvs Taberniel Antuerpianus Ioanni Commano Bibliopolæ, 1605), title page and p. 81 .

A similar practice is evidenced in the decorative capital letters that mark the beginnings of the voice parts in the Bruceña choirbook. They follow a practice initiated with 
the Liber magnificarum (1607) and followed in subsequent choirbooks. Here, two modular ornaments (see Illustrations 5 and 6) arranged in a variety of combinations provide a frame surrounding wood block initials (see Illustration 7). ${ }^{56}$ These ornaments had been used in 1605 to designate the major divisions of a volume that Tavernier printed in association with his Flemish colleague Jan Coman (see Illustrations 8 and 9). ${ }^{57}$ The fact that the same ornaments were used by Jan Poelman, Coman's uncle, in the title page of his 1581 edition of Lambin's Menaechmi provides further evidence of the ways in which Salamanca's community of Flemish printers routinely shared materials and resources. ${ }^{58}$

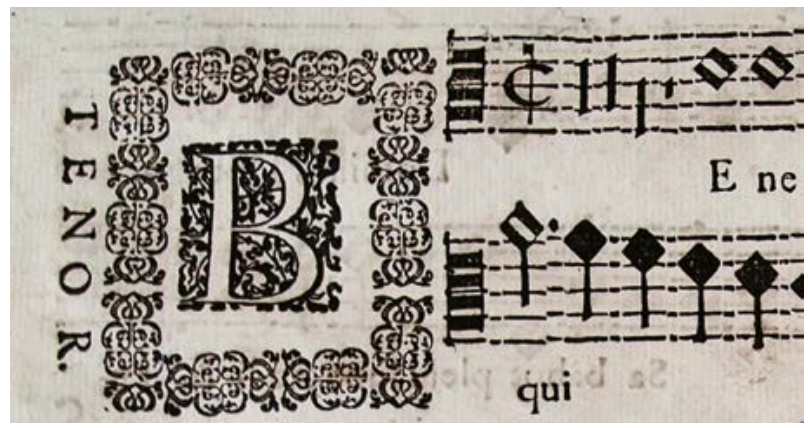

Illustration 7. Bruceña choirbook, Tenor initial 'B', p. 138.

While much of the title page of Bruceña's choirbook is missing, the remaining fragment of the lower left corner of its centerpiece engraving reveals three of the

56 The modular ornament used to provide a border for initials in the choirbooks is found, similarly deployed as a border -in this instance a border to an illustration depicting the crucifixion - in Ceremonias, usos, costumbres y señales de la congregacion de san Benito el real de Valladolid (Valladolid: Andrés de Merchán, 1599). See E-Mn <http://bdh-rd.bne.es/ viewer.vm? $\mathrm{id}=0000160003 \&$ page $=1>$.

57 Juan de Solórzano Pereira, De parricidii crimine disputatio duobus libris comprehensa (Salamanca: excudebat Artvs Taberniel Antuerpianus Ioanni Commano Bibliopolæ, 1605). For a digital exemplar, see <https://babel.hathitrust.org/cgi/pt?i $\mathrm{d}=$ ucm $.5319056655 \&$ view $=1$ up \&seq $=1>$.

58 Dionysius Lambinus, Menaechmi (Salamanca: Apud Ioannem Pulannum, 1581). See a facsimile of its title page in Frans M. A. Robben, "Jan Poelman: boekverkoper en vertegenwoordiger van de firma Plantin-Moretus in Salamanca 15791607", De Gulden passer, 71-72 (1993-1994), p. 357.
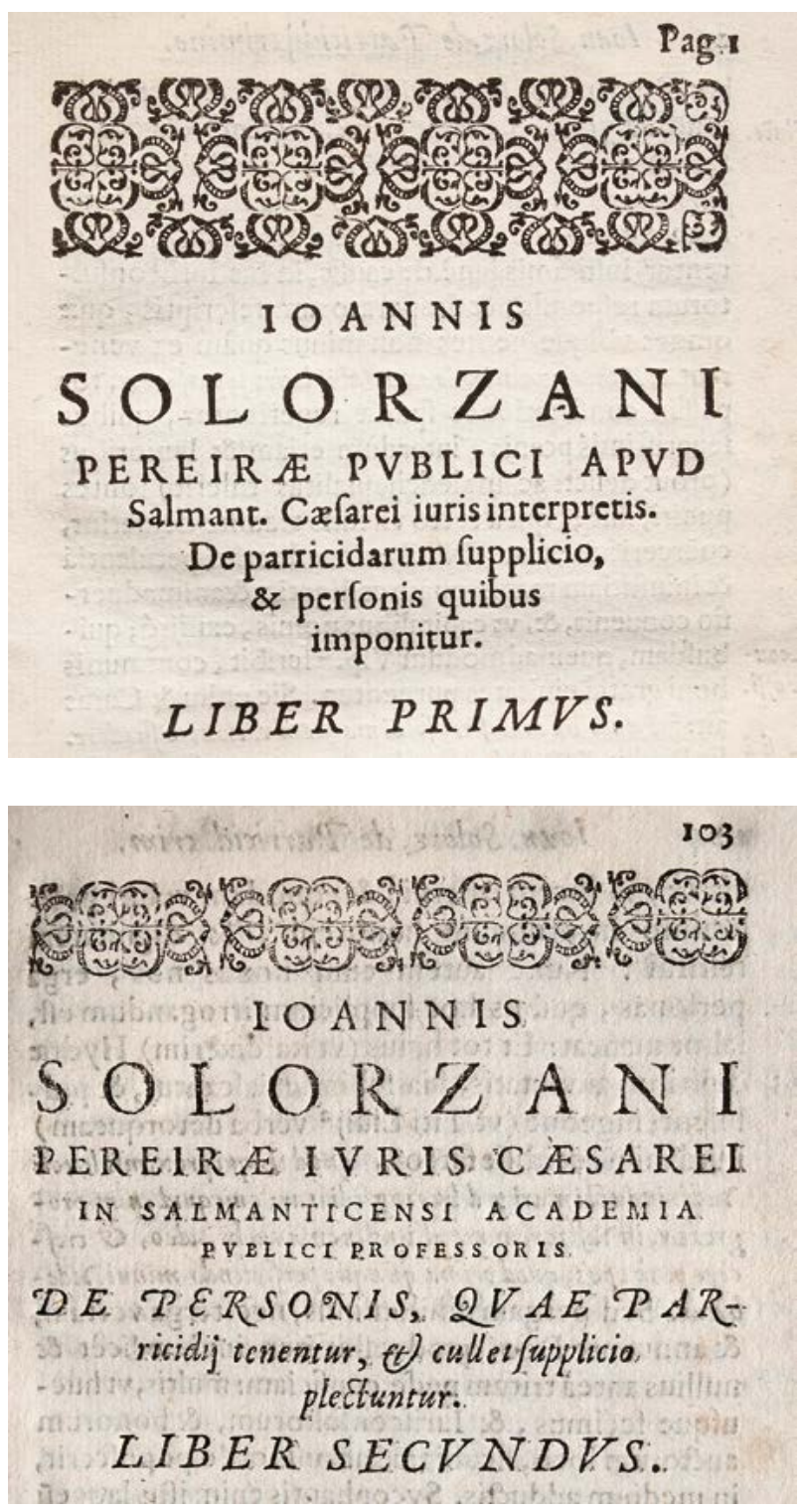

Illustrations 8 and 9. Modular ornaments from Juan de Solórzano Pereira, De parricidii crimine disputatio (Salamanca: excudebat Artvs Taberniel Antuerpianus Ioanni Commano Bibliopolæ, 1605), pp. 1 and 103.

tassels that must have hung from the Roman galero of Juan Pérez de la Serna's heraldic shield..$^{59}$ On January 18,

59 De la Serna's arms appear in the top right corner of a portrait of the archbishop owned by the Archivo histórico del Arzo- 


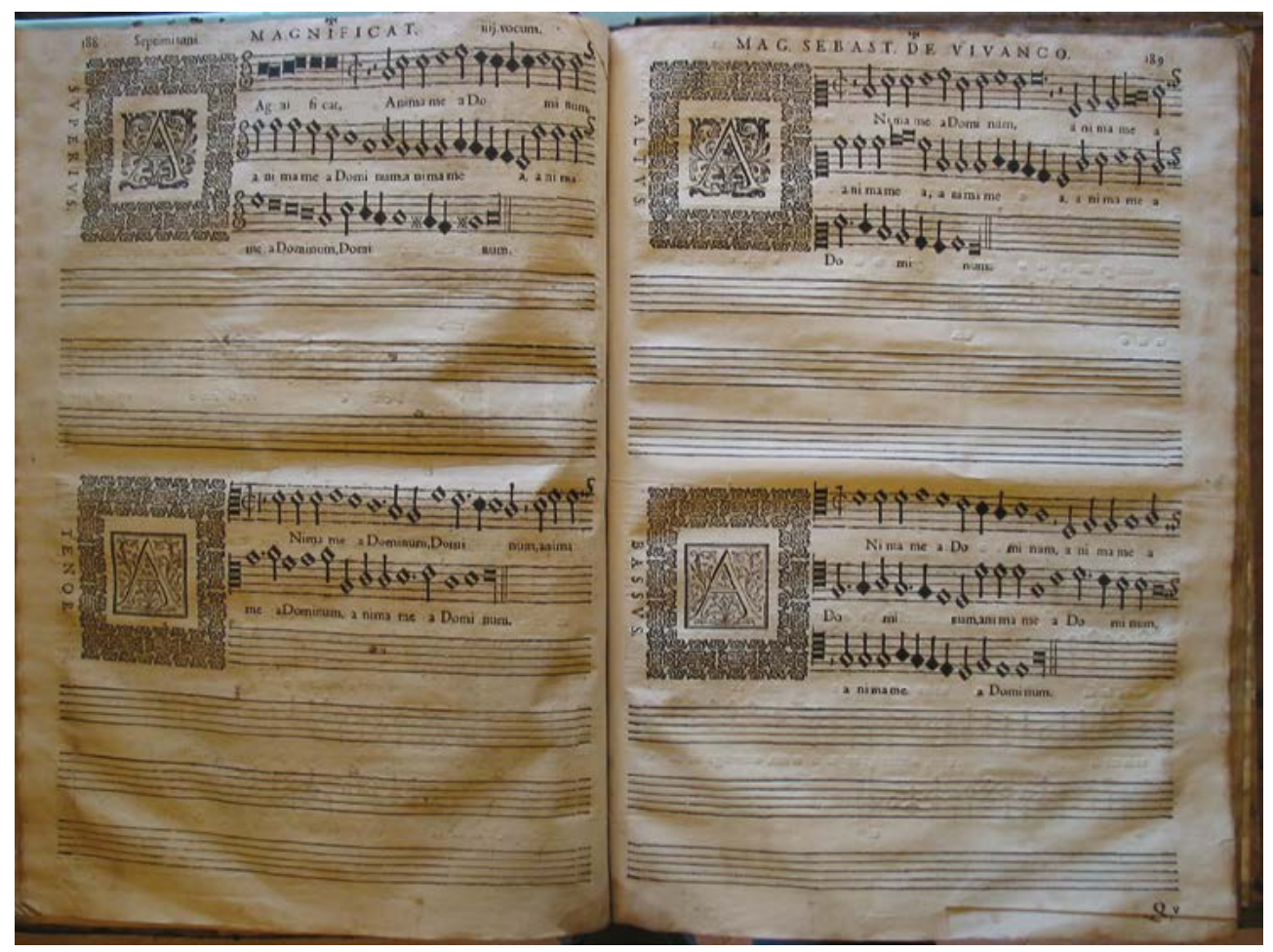

Illustration 10. Sebastiani de Vivanco Abvlensis, Liber magnificarvm (Salmanticæ: Ex Officina typographica Arti Taberniel Antuerpiani, 1607), pp. 188-189.

1613 Pérez was promoted from his position as canónigo magistral in Zamora's cathedral to archbishop of Mexico. After a long and tumultuous tenure in Mexico, he returned to Zamora in 1627.

Although the final letters of the Roman numeral date on the title page have been lost, there can be no doubt that the date was 1620. Proof of the faithful fulfillment of the contract's stipulation that the printing be completed 75 days after 9 March 1620 is found in a document attesting to Zamora cathedral's receipt of an exemplar of the choirbook sometime before 31 October $1620 .{ }^{60}$ In general terms, the choirbook's mise-en-page follows the house style that Tavernier defined in 1607 with Vivanco's Liber magnificarum

bispado de México and that is reproduced in Ballone, The 1624 tumult of Mexico, p. 172.

${ }^{60}$ ADZ, Libro de cuentas de fábrica [de la catedral] 16071623 (T. 112), fol. 314v. The printing date is given as 1621 in López-Calo, La música en la Catedral de Zamora, pp. 276-277, and López-Calo, "Diego Briceña" in Diccionario de la música, p. 696. (see Illustration 10). ${ }^{61}$ While the standard layout comprised 12 staves per page, at least 7 pages of the Bruceña choirbook are laid out with 11 staves, at least 8 have 13 staves and at least 4 pages are laid out with 14 staves. With the exception of the fragment of the title page, all evidence of the customary preliminaries that we find in the firm's six previous choirbooks is missing in this exemplar. We know from a document dated 23 February 1620, however, that Bruceña had indeed obtained the obligatory approbation and license to print.$^{62}$ It is likely that there was also a dedi-

${ }^{61}$ Many facsimiles of Vivanco's motet book are reproduced passim in García Fraile, Sebastián de Vivanco.

62 AHPZ 764 69r-70r (69r) 23FEB1620: "Sepan quantos esta carta de poder vieren como yo Diego de bruceña Raçion[er] o y maestro de Capilla de la s[an]ta yglessia catredal de esta ciudad de Zamora vecino de ella digo que por qu[an]to yo tengo escrito y ordenado un libro de mussica magnificas motetes y missas el qual esta aprovado y visto por los señores del supremo Conssexo de su maj[esta]d e para ymprimirle y sacar a luz..." See also Luis Iglesias, "El maestro de capilla" p. 463. 
catory letter, a 'tasa' stating the price at which the book would be sold, and a table of contents.

\section{THE BRUCEÑA CHOIRBOOK, CONTENTS AND MUSICAL STYLE}

Table 2 gives a summary of the choirbook's contents together with an indication, in the 'preservation' column, of the extent to which the music in missing or damaged parts of the book might be amenable to reconstruction.

Like Esquivel's Psalmorvm, Hymnorvm, Magnificarvm...Tomvs Secvndvs (1613), and unlike any of the other Salamancan choirbooks, Bruceña's anthology embraces a variety of liturgical genres. The lion's share of its 300 pages is devoted to six settings of the mass ordinary that together occupy the choirbook's first 163 pages, more than half of which are missing from the exemplar in Miranda do Douro. Inevitably, therefore, our knowledge of Bruceña's masses will remain compromised until the almost 90 missing pages come to light. The six masses are followed by a set of eight magnificat settings, one in each of the eight tones. They occupy a little less than a third of the choirbook and are followed by a group of motets occupying 35 pages. At the end of the book, we find an alternatim setting of the Marian antiphon Salve Regina, and three settings of the final versicle of the office, Benedicamus Domino.

Even the most superficial acquaintance with the contents of the Bruceña choirbook will shatter any stylistic preconceptions of Bruceña's oeuvre based on his Lauda Jerusalem 8vv (see Music Example 1). Not a single work in the choirbook is scored for more than one choir and none of the works in the choirbook is scored for more than six voices. There is little in the Bruceña choirbook that shares the polychoral idiom that we find either in the Lauda Jerusalem or in so many of the works of such older contemporaries of Bruceña as Tomás Luis de Victoria, Philippe Rogier or in the masses and motets of Sebastián de Vivanco.

All four of Bruceña's surviving masses are, to borrow Milsom's terminology, T-masses.$^{63}$ While the source motets for three of the masses are easily identified, the

${ }^{63}$ See John Milsom, "The T-Mass: quis scrutatur?", Early Music, 46 (2018), p. 320. Milsom explains the term thus: "I prefix the capital 'T-' to any genre of polyphony systematically made from multi-voiced content intentionally transferred from source for the Missa Veni de Libano remains elusive. Space permits only a few general observations and they, of course, can only be based on the works that survive. Bruceña's masses are short and concise. At 494 breves, the Missa Quae est ista is the longest and the Missa Tu es pastor ovium is the shortest, at only 347 breves. Of the three masses that survive complete, all are scored for four voices (SATB). Only once does he augment the number of voices: by adding a superius to his SATB scoring in the Agnus Dei of the Missa Veni de Libano. None of Bruceña's mass movements are canonic and none employ triple metre. Structurally, Bruceña divides his Gloria movements into two sections beginning respectively with the words Et in terra and Qui tollis. While two of his Credo movements are tripartite (Patrem, Cruxifixus, and Et in spiritum), a third is divided into only two movements (Patrem and Crucifixus). Bruceña always treats the Sanctus as a single connected movement in which the Pleni and the first Osanna are fully integrated, without pauses or intermediate cadences. Similarly, all his settings of the Benedictus include the second Osanna without a break. Bruceña consistently reduces to three voices for his Benedictus movements, though the same trio is not used more than once. ${ }^{64} \mathrm{He}$ does not reduce voices for any movement or section other than the Benedictus. As for the Agnus, Bruceña only ever gives a single movement, invariably setting the petition miserere nobis.

Bruceña's cycle of magnificat settings offers polyphony for the odd-numbered verses of the canticle in each of the eight tones. While the odd-numbered verse settings in Esquivel's Psalmorvm, Hymnorvm, Magnifcarvm were clearly designated for use at First Vespers and the even-numbered verse settings were intended for use at Second Vespers, there is no such explicit designation in what survives of the Bruceña choirbook. ${ }^{65}$ The

an existing polyphonic work or works, typically with extensive transformation of that material."

${ }^{64}$ For a discussion of Esquivel's treatment of the Sanctus and Benedictus movements in the masses of his 1608 and 1613 books, together with observations concerning wider Spanish practice, see Snow, The 1613 Print of Juan Esquivel Barahona, pp. 24-26.

${ }^{65}$ The designation for First or Second Vespers is given in both the index page and at the relevant openings of Esquivel's Psalmorvm, Hymnorvm, Magnificarvm (1613). This practice is well documented throughout Spain. See Snow, The 1613 Print of Juan Esquivel Barahona, pp. 15 and 21. 


\begin{tabular}{|c|c|c|c|}
\hline No. & Title & Voices & Preservation \\
\hline \multicolumn{4}{|c|}{ Masses } \\
\hline 1 & Mass & & missing \\
\hline 2 & Mass & & missing \\
\hline 3 & Missa Elisabeth Zachariae 4vv & SATB & incomplete \\
\hline 4 & Missa Quae est ista 4vv & SATB & some losses \\
\hline 5 & Missa Tu es pastor ovium $4 \mathrm{vv}$ & SATB & some losses \\
\hline 6 & Missa Veni de Libano $4 \mathrm{vv} / 5 \mathrm{vv}$ & S(S)ATB & some losses \\
\hline \multicolumn{4}{|c|}{ Magnificats } \\
\hline 7 & Anima mea Primi toni $4 \mathrm{vv} / 3 \mathrm{vv}$ & SATB & incomplete \\
\hline 8 & Anima mea Secundi toni $5 \mathrm{vv} / 4 \mathrm{vv} / 6 \mathrm{vv}$ & SSA(A)TB & some losses \\
\hline 9 & Anima mea Tertii toni $4 \mathrm{vv} / 3 \mathrm{vv} / ?$ ? $6 \mathrm{v}$ & S(S)ATB & incomplete \\
\hline 10 & Anima mea Quarti toni $4 \mathrm{vv} / 3 \mathrm{vv}$ & SATB & some losses \\
\hline 11 & Anima mea Quinti toni $4 \mathrm{vv} / 3 \mathrm{vv} / 6 \mathrm{vv}$ & $\mathrm{S}(\mathrm{S}) \mathrm{A}(\mathrm{A}) \mathrm{TB}$ & complete \\
\hline 12 & Anima mea Sexti toni 4vv/3vv & S(S)ATB & complete \\
\hline 13 & Anima mea Septimi toni $4 \mathrm{vv} / 3 \mathrm{vv} / 6 \mathrm{vv}$ & $\mathrm{S}(\mathrm{S}) \mathrm{A}(\mathrm{A}) \mathrm{TB}$ & small losses \\
\hline 14 & Anima mea Octavi toni $4 \mathrm{vv} / 3 \mathrm{vv} / 6 \mathrm{vv}$ & $\mathrm{S}(\mathrm{S}) \mathrm{A}(\mathrm{A}) \mathrm{TB}$ & complete \\
\hline \multicolumn{4}{|c|}{ Motets } \\
\hline 15 & Tribulationes cordis mea $6 \mathrm{vv}$ & SSAATB & complete \\
\hline 16 & Hoc est praeceptum meum $6 \mathrm{vv}$ & SSAATB & complete \\
\hline 17 & Iste sanctus $6 \mathrm{vv}$ & SSAATB & complete \\
\hline 18 & Ave sanctissima Maria $6 \mathrm{vv}$ & SSAATB & complete \\
\hline 19 & Stabat mater $5 \mathrm{vv}$ & SSATB & complete \\
\hline 20 & O Ildefonse 4vv & SATB & complete \\
\hline 21 & Gaudent in caelis $4 \mathrm{vv}$ & SATB & complete \\
\hline 22 & Hic vir despiciens mundum $4 \mathrm{vv}$ & SATB & complete \\
\hline 23 & O doctor optime $4 \mathrm{vv}$ & SATB & complete \\
\hline 24 & Assumpsit Jesus Petrum 4vv & SSAT & complete \\
\hline 25 & Veni sponsa Christi 4vv & SATB & complete \\
\hline 26 & Amavit eum Dominus 4vv & SATB & complete \\
\hline \multicolumn{4}{|c|}{ Marian antiphon and Benedicamus } \\
\hline 27 & Salve regina $5 \mathrm{vv}$ & SSATB & incomplete \\
\hline 28 & Benedicamus & SATB & incomplete \\
\hline 29 & Benedicamus & SATB & incomplete \\
\hline 30 & ? Benedicamus & & missing \\
\hline
\end{tabular}

Table 2. The Bruceña choirbook, summary of contents. 


\begin{tabular}{|c|c|c|c|c|c|c|c|c|}
\hline $\begin{array}{l}\text { Tone } \\
\& \text { final }\end{array}$ & Verse 1 & Verse 3 & Verse 5 & Verse 7 & Verse 9 & Verse 11 & Intervallic distance & $\begin{array}{c}\text { Temporal } \\
\text { distance }\end{array}$ \\
\hline $\begin{array}{c}1, \\
\text { G final }\end{array}$ & $\begin{array}{c}\varnothing \\
\text { SATB }\end{array}$ & $\begin{array}{c}\varnothing \\
\text { SATB }\end{array}$ & $\begin{array}{c}\varnothing \\
\text { SAT }\end{array}$ & $\begin{array}{c}\phi \\
\text { SATB }\end{array}$ & $\begin{array}{c}\phi \\
\text { SA[TB] }\end{array}$ & missing & & \\
\hline $\begin{array}{c}2, \\
\text { G final }\end{array}$ & $\begin{array}{c}\phi \\
\text { SSATB }\end{array}$ & $\begin{array}{c}\phi \\
\text { SSATB } \\
\end{array}$ & $\begin{array}{c}\varnothing \\
\text { SSAT }\end{array}$ & $\begin{array}{c}\not \\
\text { SSATB } \\
\end{array}$ & $\begin{array}{c}\varnothing \\
\text { SSATB } \\
\end{array}$ & $\begin{array}{c}\phi \\
\underline{\text { SSAATB }}\end{array}$ & unison & 1.5 breves \\
\hline $\begin{array}{c}3, \\
\text { A final }\end{array}$ & $\begin{array}{c}\phi \\
\text { SATB }\end{array}$ & $\begin{array}{c}\phi \\
\text { SATB }\end{array}$ & $\begin{array}{c}\phi \\
3 \mathrm{vV} A \mathrm{AA} ?\end{array}$ & missing & missing & $\begin{array}{c}\phi: \\
\underline{\text { SSSAATB }}\end{array}$ & $\begin{array}{l}\text { S1 in diatesaron } \\
\text { (S1 at the upper 4th) }\end{array}$ & \\
\hline $\begin{array}{l}4, \\
\text { E final }\end{array}$ & $\begin{array}{c}\varnothing \\
\text { SATB }\end{array}$ & $\begin{array}{c}\varnothing \\
\text { SATB }\end{array}$ & $\begin{array}{c}\varnothing \\
\text { SAT }\end{array}$ & $\begin{array}{c}\varnothing \\
\text { SATB }\end{array}$ & $\begin{array}{c}\varnothing \\
\text { SATB }\end{array}$ & $\begin{array}{l}\phi 3 / 2: \mathrm{SA} \\
\phi 3 / 2: \mathrm{TB}\end{array}$ & & \\
\hline $\begin{array}{c}5, \\
\text { A final }\end{array}$ & $\begin{array}{c}\varnothing \\
\text { SATB }\end{array}$ & $\begin{array}{c}\varnothing \\
\text { SATB }\end{array}$ & $\begin{array}{c}\varnothing \\
\text { SAT }\end{array}$ & $\begin{array}{c}\varnothing \\
\text { SATB }\end{array}$ & $\begin{array}{c}\varnothing \\
\text { SATB }\end{array}$ & $\begin{array}{c}\phi \\
\text { SSA } \underline{\underline{A T B}}\end{array}$ & $\begin{array}{l}\text { A2 in diapente } \\
\text { (A2 at the upper } 5 \text { th) }\end{array}$ & 1 breve \\
\hline $\begin{array}{c}6, \\
\text { F final }\end{array}$ & $\begin{array}{c}\varnothing \\
\text { SATB }\end{array}$ & $\begin{array}{c}\varnothing \\
\text { SATB }\end{array}$ & $\begin{array}{c}\phi \\
\text { SAT }\end{array}$ & $\begin{array}{c}\varnothing \\
\text { SATB }\end{array}$ & $\begin{array}{c}\varnothing \\
\text { SATB }\end{array}$ & $\begin{array}{c}\varnothing \\
\text { SSAT }\end{array}$ & & \\
\hline $\begin{array}{c}7, \\
\text { A final }\end{array}$ & $\begin{array}{c}\varnothing \\
\text { SATB } \\
\end{array}$ & $\begin{array}{c}\varnothing \\
\text { SATB } \\
\end{array}$ & $\begin{array}{c}\varnothing \\
\text { ATB }\end{array}$ & $\begin{array}{c}\phi \\
\text { SATB } \\
\end{array}$ & $\begin{array}{c}\varnothing \\
\text { SATB } \\
\end{array}$ & $\begin{array}{c}\phi \\
\text { SSA } \underline{\mathbf{A} T} \underline{\mathbf{B}}\end{array}$ & $\begin{array}{c}\text { A2 in septima } \\
\text { (A2 at the upper } 7 \text { th) }\end{array}$ & 1.5 breves \\
\hline $\begin{array}{c}8, \\
\text { G final }\end{array}$ & $\begin{array}{c}\varnothing \\
\text { SATB }\end{array}$ & $\begin{array}{c}\not \\
\text { SATB }\end{array}$ & $\begin{array}{c}\varnothing \\
\text { SAT }\end{array}$ & $\begin{array}{c}\varnothing \\
\text { SATB }\end{array}$ & $\begin{array}{c}\varnothing \\
\text { SATB }\end{array}$ & $\begin{array}{c}\phi \\
\text { SSAATB }\end{array}$ & $\begin{array}{c}\mathrm{T} \text { in diapason } \\
\text { ( } \mathrm{T} \text { at the upper octave), } \\
\mathrm{A} 2 \text { in diapente } \\
\text { (A2 at the lower } 5 \mathrm{th}) \text {, } \\
\mathrm{B} \text { in duodecima } \\
\text { (B at the lower } 12 \mathrm{th} \text { ) }\end{array}$ & $\begin{array}{l}1 \text { breve } \\
1.5 \text { breves } \\
2.5 \text { breves }\end{array}$ \\
\hline
\end{tabular}

Table 3. Summary overview of Bruceña's magnificat cycle ${ }^{66}$

predominance of odd-verse settings among the magnificats of Juan García de Salazar (Zamora cathedral's maestro de capilla from 1668 to 1710) might, however, suggest that in Zamora cathedral odd-verse settings were more frequently called for at Vespers than were evenverse or plenary settings. ${ }^{67}$ And while his set of eight canticles belongs to the great Spanish tradition of magnificat cycles by such composers as Morales, Guerrero, Esquivel, Vivanco, and Victoria, Bruceña's is clearly a modest contribution to that tradition. ${ }^{68}$ Table 3 offers a summary

${ }^{66}$ Canonic voices are given in bold face and underlined. Missing voices are indicated by a question mark.

${ }^{67}$ Alejandro Luis Iglesias, En torno al barroco musical español: el oficio y la misa de difuntos de Juan García de Salazar (Salamanca: Ediciones Universidad de Salamanca y Colegio Universitario de Zamora, 1989), pp. 26-27 and 33-35.

${ }^{68}$ On the magnificat as a genre in Spain, see the survey in José María Llorens Cisteró, Francisco Guerrero, Opera Omnia: overview of Bruceña's magnificat cycle. Seven of the magnificats are scored for four voices (SATB) and an eighth, the Magnificat Secundi toni, is scored for five voices (SSATB). In all eight magnificats, verse 5 (Et misericordia) is scored for one voice less than the prevailing texture and verse 11 (Gloria Patri) is differentiated by one or more of the following treatments: the augmentation of vocal scoring (in at least five instances), a change in vocal scoring (in at least one instance), the choice of triple metre (in at least one instance), and the canonic treatment of one or more voices (in at least five instances). Verse 11 of Bruceña's Magnificat Octavi toni brings the entire cycle to a climactic denouement in which all

Magnificat per omnes tonos, Monumentos de la Música Española, vol. 56 (Barcelona: Consejo Superior de Investigaciones Científicas, 1999), vol. 10, pp. 15-90 and Joseph Sargent, "The polyphonic magnificat in Renaissance Spain” (Ph.D. diss., Stanford University, 2009). 
voices (SSAATB) sing a paraphrase of the eighth magnificat tone in a triumphant six-in-two canon.

The group of twelve motets is the only section of the choirbook to have survived without significant loss or damage. The composer's unusual choice of texts, with no fewer than seven motets for use in the commune sanctorum and no motets designated for the major feasts of the temporale, stands in stark contrast to most calendrically ordered motet collections of the post-Tridentine era. This is perhaps a reflection of local Zamoran use. Of the seven motets scored for four voices, the Transfiguration motet Assumpsit Jesus Petrum is scored for a suitably incandescent group of high voices (SSAT) while the remaining six are scored for SATB. Only one motet, the Stabat mater, is scored for SSATB. The four motets scored for six voices (SSAATB) follow a pattern that is repeated throughout the choirbook: when Bruceña adds voices beyond the SATB complement, it is higher voices that he adds to his palette. Not a single movement or work calls for more than one tenor or more than one bass. Bruceña's motets share the same brevity that we observed in the masses. Seven motets occupy single openings of the choirbook, four occupy two openings, and only one, the Ave sanctissima Maria, occupies as many as three openings.

The final section of our choirbook, occupying only twelve pages, comprises a Salve Regina and three settings of the Benedicamus. All four works are either incomplete or missing entirely. Alternatim settings of the Salve Regi$n a$ by Iberian composers were not all based on the same version of the chant, and they exhibit a wide variety of minor variants in the text. This diversity of treatment is also apparent in the three verses that were set polyphonically: Vita dulcedo (SSATB), Ad te suspiramus (SSAT), and Nobis post hoc (SSATB). ${ }^{69}$ Not one of the three Benedicamus settings at the end of the book survives complete.

${ }^{69}$ On the Salve service and versions of the Salve chant, see Robert J. Snow, ed., A New-World Collection of Polyphony for Holy Week and the Salve Service: Guatemala City, Cathedral Archive, Music MS 4, Monuments of Renaissance Music, vol. 9 (Chicago \& London: University of Chicago Press, 1996), pp. 65-78; Michael O’Connor, "The Polyphonic Marian Antiphon in Renaissance Spain”, in Treasures of the Golden Age, ed. Michael O'Connor and Walter Clark (Hillsdale, NY: Pendragon, 2012), pp. 87-115, and Bernadette Nelson, "From Anchieta to Guerrero: The Salve Regina in Portuguese Sources and an Unknown Early Spanish Alternatim Setting", Revista Portuguesa de Musicologia, 6 (2019), pp. 113-156.
If Bruceña's anthology was the composer's first and only choirbook, it was the seventh and last that would emerge from the printing firm owned and managed by Susana Muñoz in partnership with one or other of her three husbands. While the choirbook offers a repertory that promises further insights into Latin liturgical music in the first decades of the 17th century in Zamora, it brings to a close a period that witnessed Spain's most prolific production of printed choirbooks: seven in the space of thirteen years. And while Susana Muñoz's story is untold and her contribution to the printing of sacred music in Spain awaits exploration, our understanding of the relationship between music and print in early modern Spain will remain sadly incomplete.

The inventory that follows is designed to give as complete an accounting as possible of the Bruceña choirbook as it survives in Miranda do Douro together with what can be determined about the parts and contents of the book that do not survive. This inventory is offered with the hope that it will aid the recovery, in whole or in part, of other exemplars of the Bruceña book and that it will assist in identifying previously unattributed concordances in manuscript copies.

In the inventory, a standardized title as used in modern liturgical books is given in bold type for each piece. Elsewhere, original spelling and orthography has been retained as much as possible. Full texts of the motets, for example, are given in diplomatic transcriptions together with a source, usually liturgical or scriptural, for the text when that source can be identified. The inventory records running titles on all pages of the choirbook; those on odd-numbered pages give the title of the piece, and the number of voices for which it is scored and those on even-numbered pages give a Latin form of the composer's name. In the choirbook's running titles, each magnificat is identified by its tone. In the case of motets, a liturgical designation is given. Incipits are given as photographic reproductions of all surviving voices. ${ }^{70}$ The source motets of T-masses are given when known and such performance instructions as 'SVPERIVS TACET' are transcribed without comment. Text that is the result of the author's reasoning is given in square brackets and doubts are expressed by a question mark.

${ }^{70}$ For permission to reproduce these images, I thank the Museu da Terra de Miranda and its director Celina Bárbaro Pinto. 


\section{INVENTORY}

\begin{tabular}{|c|c|}
\hline Page & Content \\
\hline & blank paper page pasted to inside front cover \\
\hline & $\begin{array}{l}\text { Title page } \\
\text { A fragment of the lower inside quadrant is all that remains of the torn title page: } \\
\text { SVPERIORVM [PERMISSV] } \\
\text { SALMA[N]T[ICÆ] } \\
\text { Ex officina typographica ANTONIJ V[AZQUEZ] } \\
\text { Anno à Christo nato M. DC. }\end{array}$ \\
\hline & $\begin{array}{l}\text { [Mass] } \\
\text { Missing. }\end{array}$ \\
\hline & $\begin{array}{l}\text { [Mass] } \\
\text { Missing. }\end{array}$ \\
\hline $87-93$ & $\begin{array}{l}\text { Missa Elisabeth Zachariae (4vv) } \\
92 \text { MISSA ELISABETH ZACHARIE. iiij vocum. // DIDACVS DE BRVCENA. } 93 \\
\text { Kyrie, Gloria, and Credo: missing. } \\
\text { Sanctus ([86]-[89]): Superius and Tenor missing; small losses from Altus and Bassus; Osanna in } ₫ 3 / 2 \text {. } \\
\text { The upper outside quadrant of pp. } 87-88 \text { survives, detached from the book. Most of the Altus and some } \\
\text { of the Bassus is preserved on p. } 87 \text { while most of the Superius and some of the Tenor is preserved on } \\
\text { p. 88. A small fragment of the outer side of pp. [89]-[90] survives, detached from the binding. It } \\
\text { preserves some notes from the Bassus of the Sanctus and the Tenor of the Benedictus. } \\
\text { Benedictus ([90]-91): 3vv (SAT), Altus complete; Superius missing, significant losses from Tenor. }\end{array}$ \\
\hline & $\underbrace{E-1}_{\mathrm{C} \text { nus } \mathrm{De}}$ \\
\hline & $\begin{array}{l}\text { Agnus (92-3): Superius, Altus, Tenor complete; Bassus lacks most of final stave. } \\
\text { Source motet: Francisco Guerrero, Elisabeth Zachariae (secunda pars: Dominus ab utero) 5vv (SSTTB) } \\
\text { from Motteta (Venice: Filios Antonii Gardani, 1570) [RISM G4871], no. } 48 \text { and Motecta (Venice: } \\
\text { Giacomo Vincenti, 1597) [RISM G4877], no. 47. }\end{array}$ \\
\hline
\end{tabular}




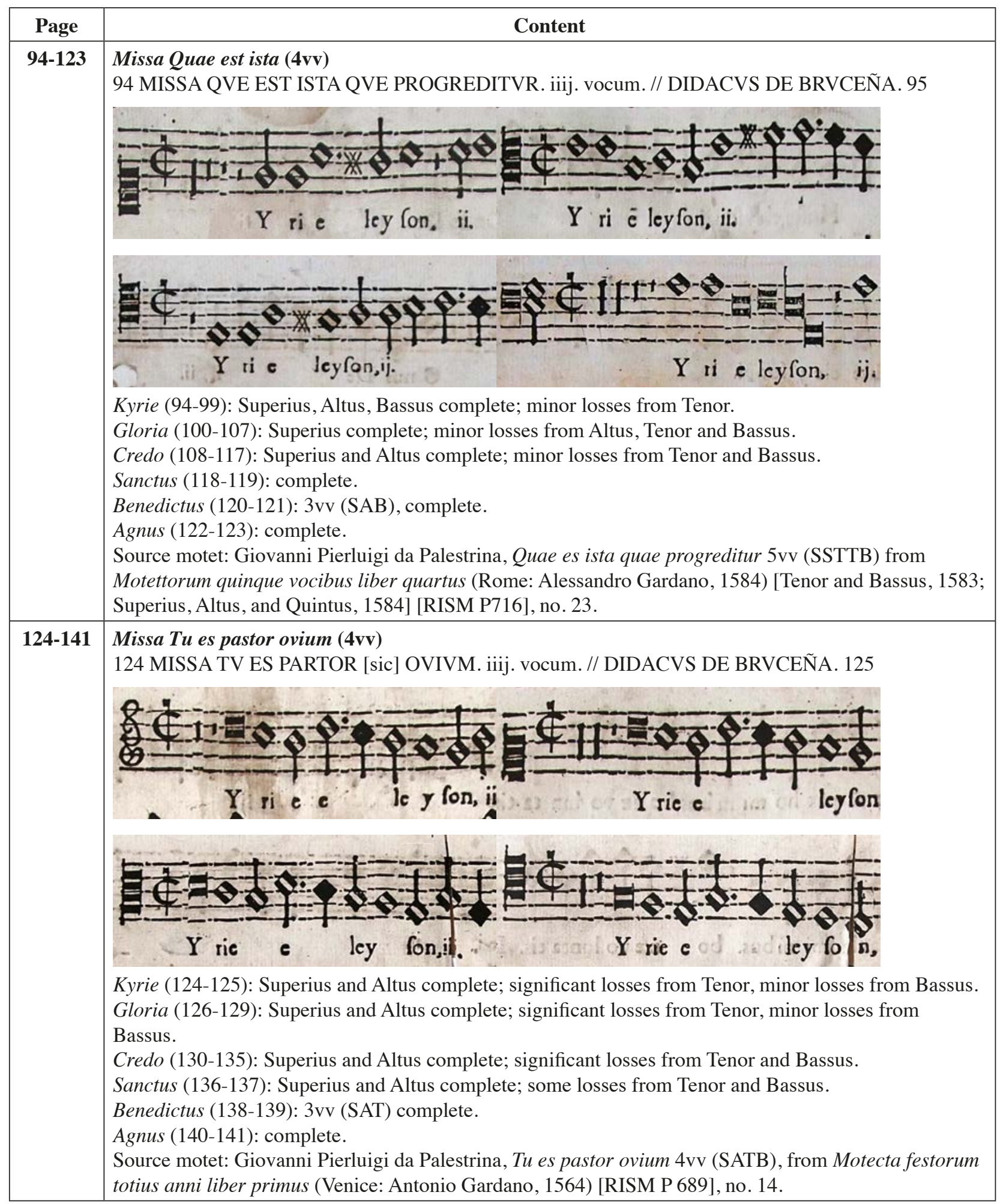




\begin{tabular}{|c|c|}
\hline Page & Content \\
\hline $142-163$ & $\begin{array}{l}\text { Missa Veni de Libano (4vv) } \\
142 \text { MISSA VENI DE LIBANO. iiij. vocum. // DIDACVS DE BRVCENA. } \\
\text { Kyrie (142-143): Superius, Altus, and Bassus complete; losses from Tenor. } \\
\text { Gloria (144-147): complete. } \\
\text { Credo (148-157): Superius and Altus complete; significant losses from Tenor and Bassus. } \\
\text { Sanctus (158-159): complete. } \\
\text { Benedictus (160-161): } 3 \mathrm{vv} \text { (ATB) complete. SVPERIVS TACET. } \\
\text { Agnus (162-163): 5vv (SSATB) complete. } \\
\text { Identity of mass model (Veni de Libano) yet to be determined. }\end{array}$ \\
\hline $\begin{array}{c}\text { 164- } \\
{[175]}\end{array}$ & $\begin{array}{l}\text { Magnificat Primi toni (4vv/3vv) } \\
164 \text { PRIMI TONI. iiij. vocum // DIDACVS DE BRVCENA. } 165 \\
\text { Pages 173-175 missing. } \\
\text { Nima mea (164-165): 4vv (SATB) complete. } \\
\text { Quia respexit (166-167): 4vv (SATB) complete. } \\
\text { Et misericordia (168-169): } 3 \mathrm{vv} \text { (SAT) complete. BASVS REQVIESCIT. } \\
\text { Deposuit (170-171): 4vv (SATB) complete. } \\
\text { Suscepit (172-[173]): 4vv (SATB) Superius and Tenor complete; Altus and Tenor missing. } \\
\text { Gloria patri ([174-175]): missing. }\end{array}$ \\
\hline
\end{tabular}




\begin{tabular}{|c|c|}
\hline Page & Content \\
\hline $\begin{array}{c}{[176]-} \\
187\end{array}$ & 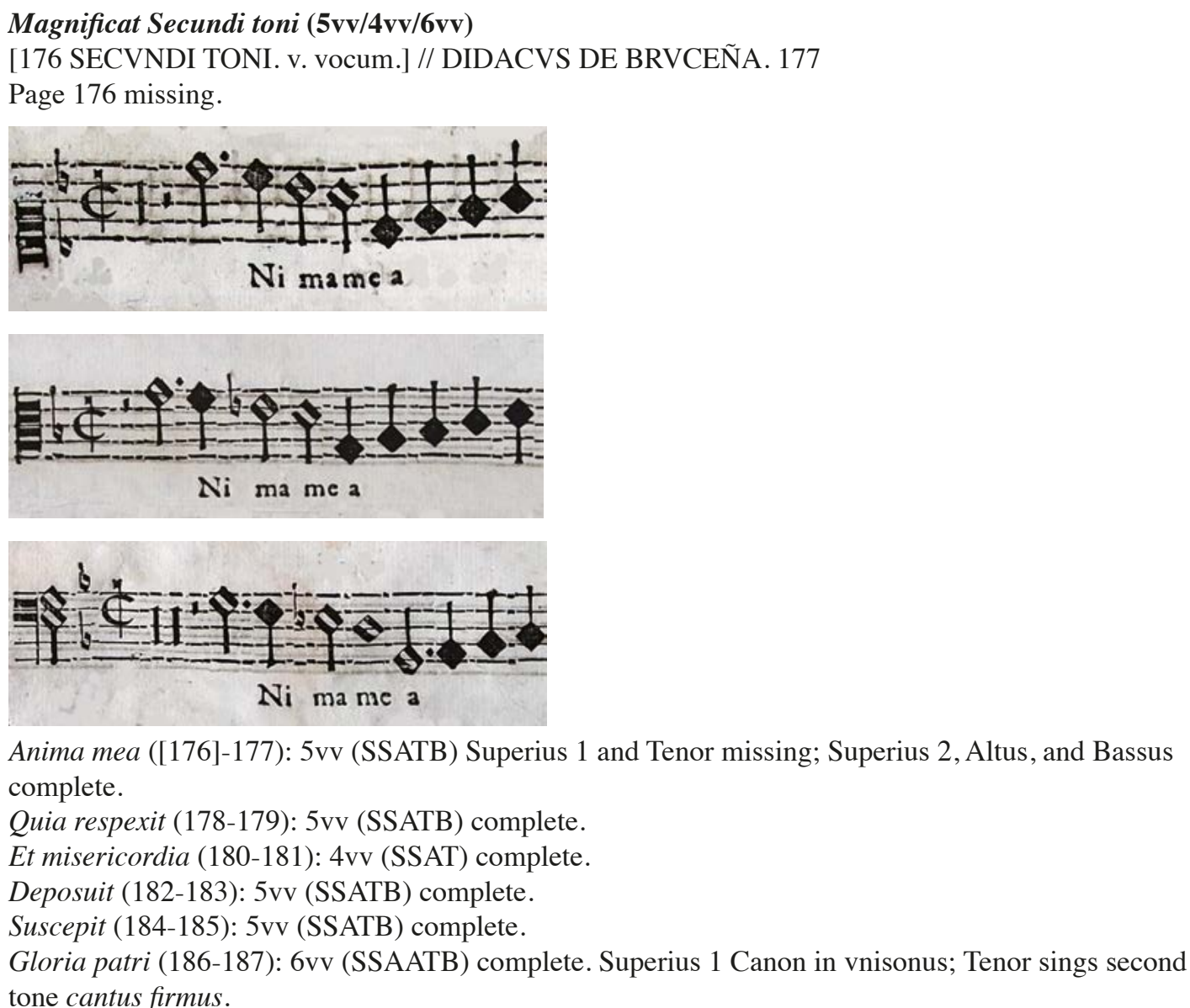 \\
\hline
\end{tabular}




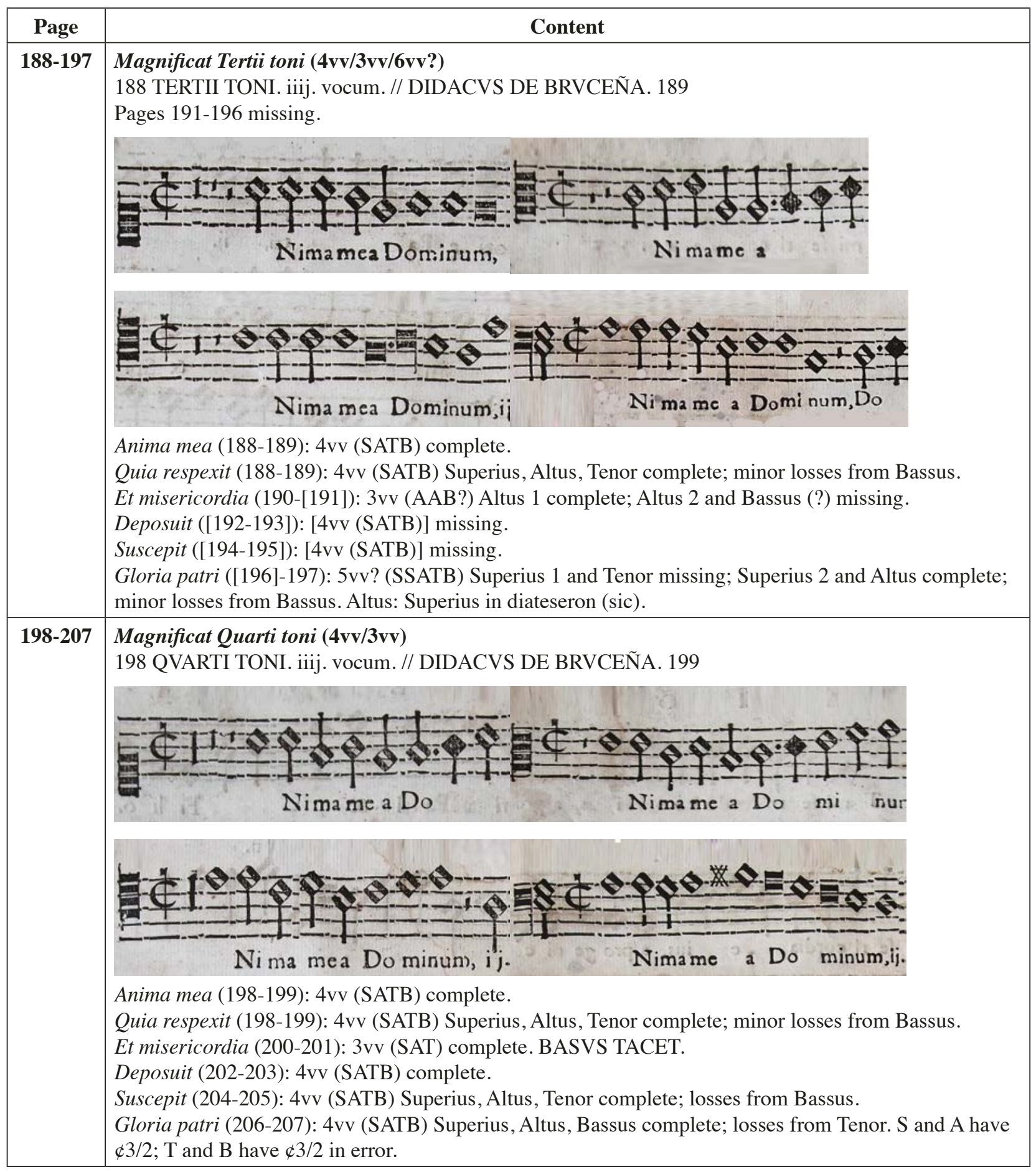




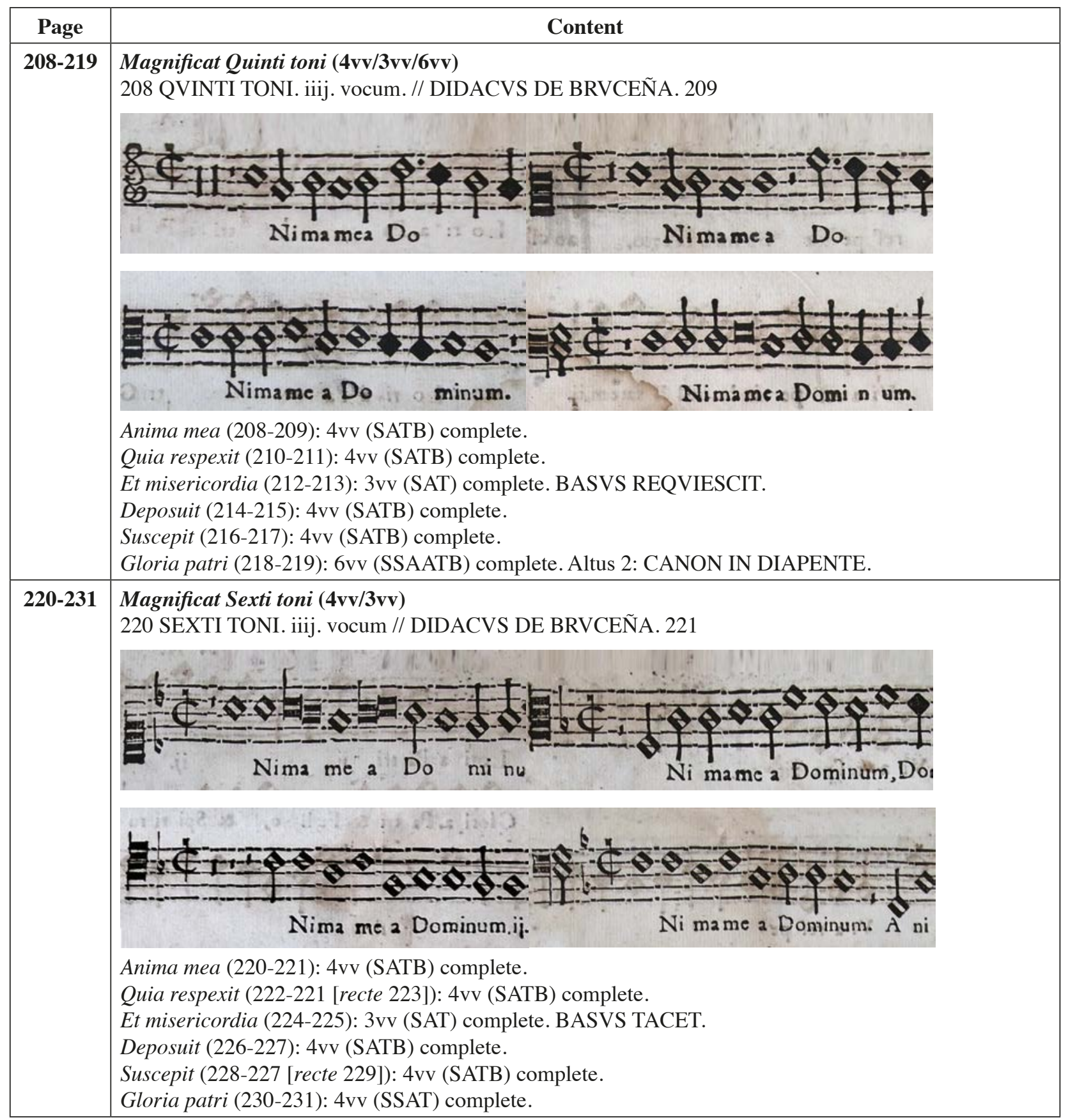




\begin{tabular}{|c|c|}
\hline Page & Content \\
\hline $232-241$ & $\begin{array}{l}\text { Magnificat Septimi toni (4vv/3vv/6vv) } \\
232 \text { SEPTIMI TONI. iij. vocum. // DIDACVS DE BRVCENA. } 233 \\
\text { Anima mea (232-233): 4vv (SATB) complete. } \\
\text { Quia respexit (232-233): 4vv (SATB) complete. } \\
\text { Et misericordia (234-235): 3vv (ATB) complete. SVPERIVS TACET. } \\
\text { Deposuit (236-237): (SATB) complete. } \\
\text { Suscepit (238-239): 4vv (SATB) complete. } \\
\text { Gloria patri (240-241): 6vv (SSAATB) Superius 1, Superius 2, Altus 1, Altus 2, Bassus complete; minor } \\
\text { losses from Tenor; Altus 1: Resolutio in Septima, Bassus: CANON Altus in Septima. }\end{array}$ \\
\hline $242-251$ & $\begin{array}{l}\text { Magnificat Octavi toni (4vv/3vv/6vv) } \\
242 \text { OCTAVI TONI. iiij. vocum // DIDACVS DE BRVCENA. } 243 \\
\text { Anima mea (242-243): 4vv (SATB) complete. } \\
\text { Quia respexit (242-243): 4vv (SATB) complete. } \\
\text { Et misericordia (244-245): } 3 \mathrm{vv} \text { (SAT) complete. BASVS REQVIESCIT. } \\
\text { Deposuit (246-247) 4vv (SATB) complete. } \\
\text { Suscepit (248-249): 4vv (SATB) complete. } \\
\text { Gloria patri (250-251): 6vv (SSAATB) complete. Canon. Tenor. In diapason. Altus. In diapente. Basus. } \\
\text { In duodezima. vj. vocu[m]. }\end{array}$ \\
\hline
\end{tabular}




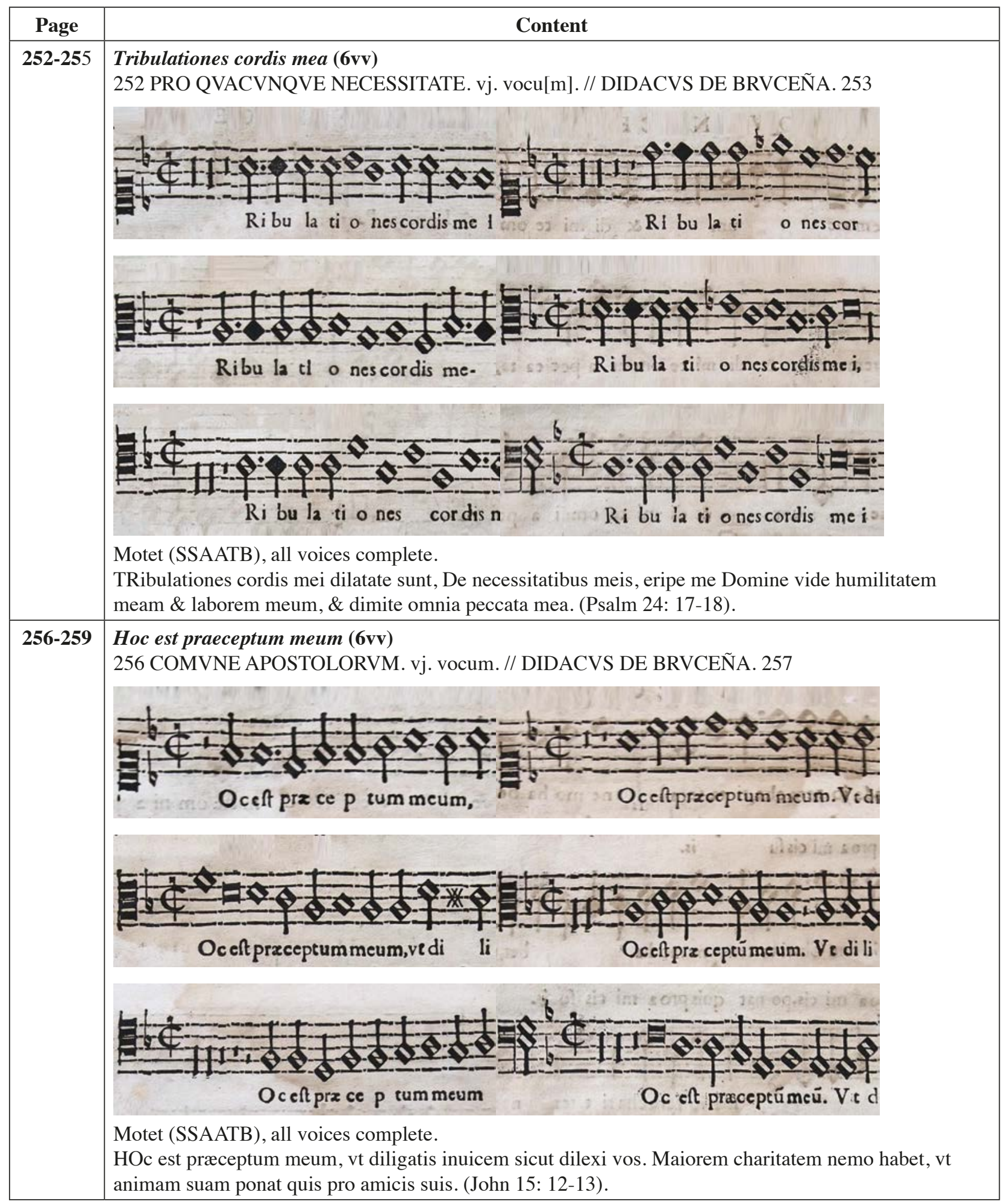




260-263
Iste Sanctus (6vv)
260 COMVNE VNIVS MARTIRIS. vj. vocu[m]. // DIDACVS DE BRVCENA. 261
ISte sanctus pro lege Dei sui, certauit vsque ad mortem, \& à verbis impiorum non timuit fundatus enim
erat supra firmam petram. (Antiphon at the magnificat, common of a martyr).




\begin{tabular}{|c|c|}
\hline Page & Content \\
\hline \multirow[t]{5}{*}{ 264-269 } & $\begin{array}{l}\text { Ave sanctissima Maria (6vv) } \\
264 \text { DE VEATA VIRGINE. vj. vocum. // DIDACVS DE BRVCEÑA. } 265\end{array}$ \\
\hline & $\begin{array}{c}\text { Ve fanciffi } \\
\text { ma Ma ri a. A }\end{array}$ \\
\hline & Ve fanctir fi maMari a, \\
\hline & 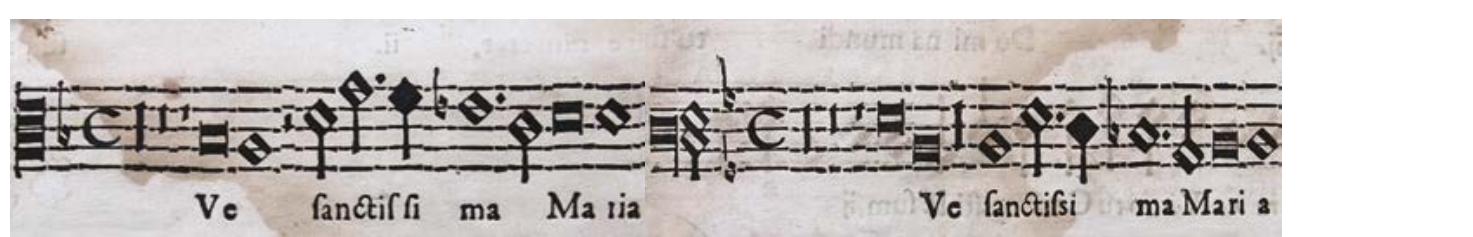 \\
\hline & $\begin{array}{l}\text { Motet (SSAATB), all voices complete. Words tu singularis set in } \phi 3 / 2 \text {. S } 1 \text { and } \mathrm{S} 2 \text { have } \phi 3 / 2 \text { in error. } \\
\text { AVe sanctissima Maria. Mater Dei, Regina cœli, Porta Paradisi, Domina mundi, tu singularis pura es } \\
\text { Virgo tu Concepisti Iesum sine peccato, libera me ab omni malo, \& ora pro peccatis meis. (Marian devo- } \\
\text { tional antiphon, Breviarium Romanum completissimum [Venice: Lucantonio Giunta, 1522] fol. 23v. }\end{array}$ \\
\hline
\end{tabular}




\begin{tabular}{|c|c|}
\hline Page & Content \\
\hline $270-273$ & $\begin{array}{l}\text { Stabat mater (5vv) } \\
270 \text { DE BEATA VIRGINE. vj. [sic] vocum. // DIDACVS DE BRVCENA. }\end{array}$ \\
\hline
\end{tabular}




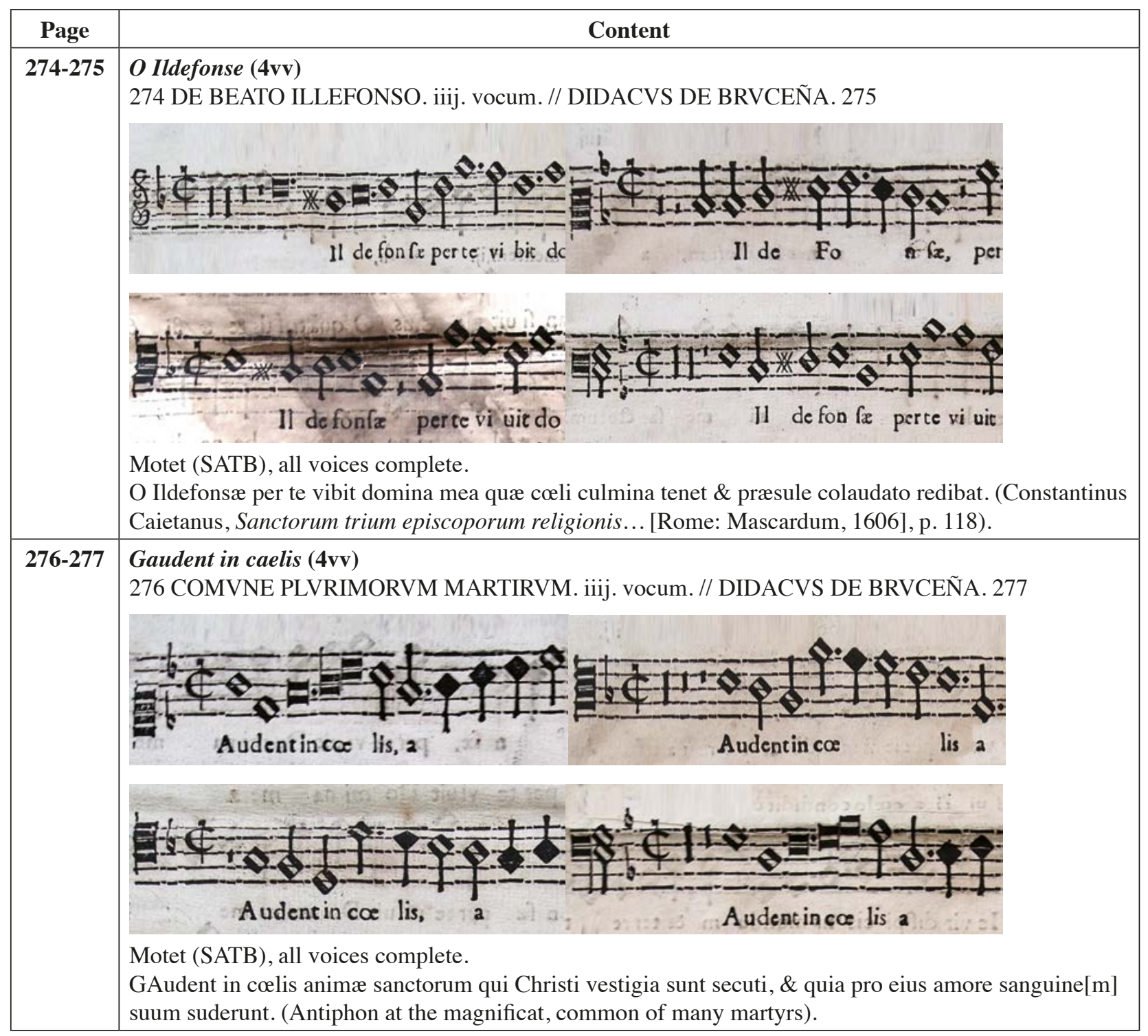




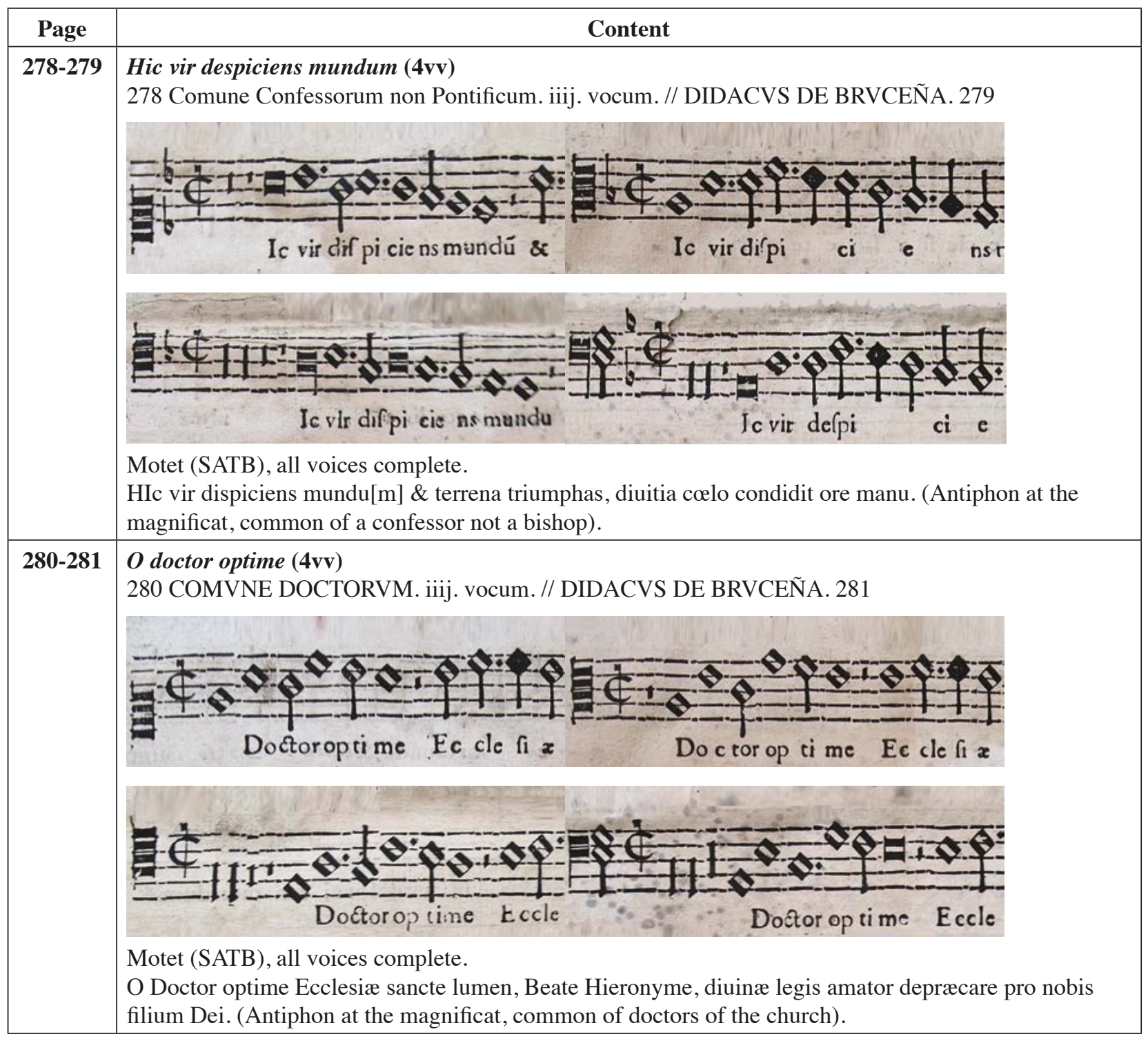




\begin{tabular}{|c|c|}
\hline Page & Content \\
\hline $282-283$ & $\begin{array}{l}\text { Assumpsit Jesus Petrum (4vv) } \\
282 \text { In transfiguracione Domini. iiij. vocum. // DIDACVS DE BRVCENA. } 281 \text { [recte 283] } \\
\text { Motet (SSAT), all voices complete. } \\
\text { ASumpsit Iesus Petrum \& Iacobum \& Ioannem fratre[m] eius, eduxit eos in montem excelsum seorsum } \\
\& \text { transfiguratus est ante eos. (Matthew 17, 1-2a). } \\
\text { The first note in the fourth stave of the Tenor has been corrected by hand to F sharp. }\end{array}$ \\
\hline 284-285 & $\begin{array}{l}\text { Veni sponsa Christi (4vv) } \\
284 \text { COMVNE VIRGINVUM. iiij. vocum. // DIDACVS DE BRVCENA. } 28\end{array}$ \\
\hline
\end{tabular}




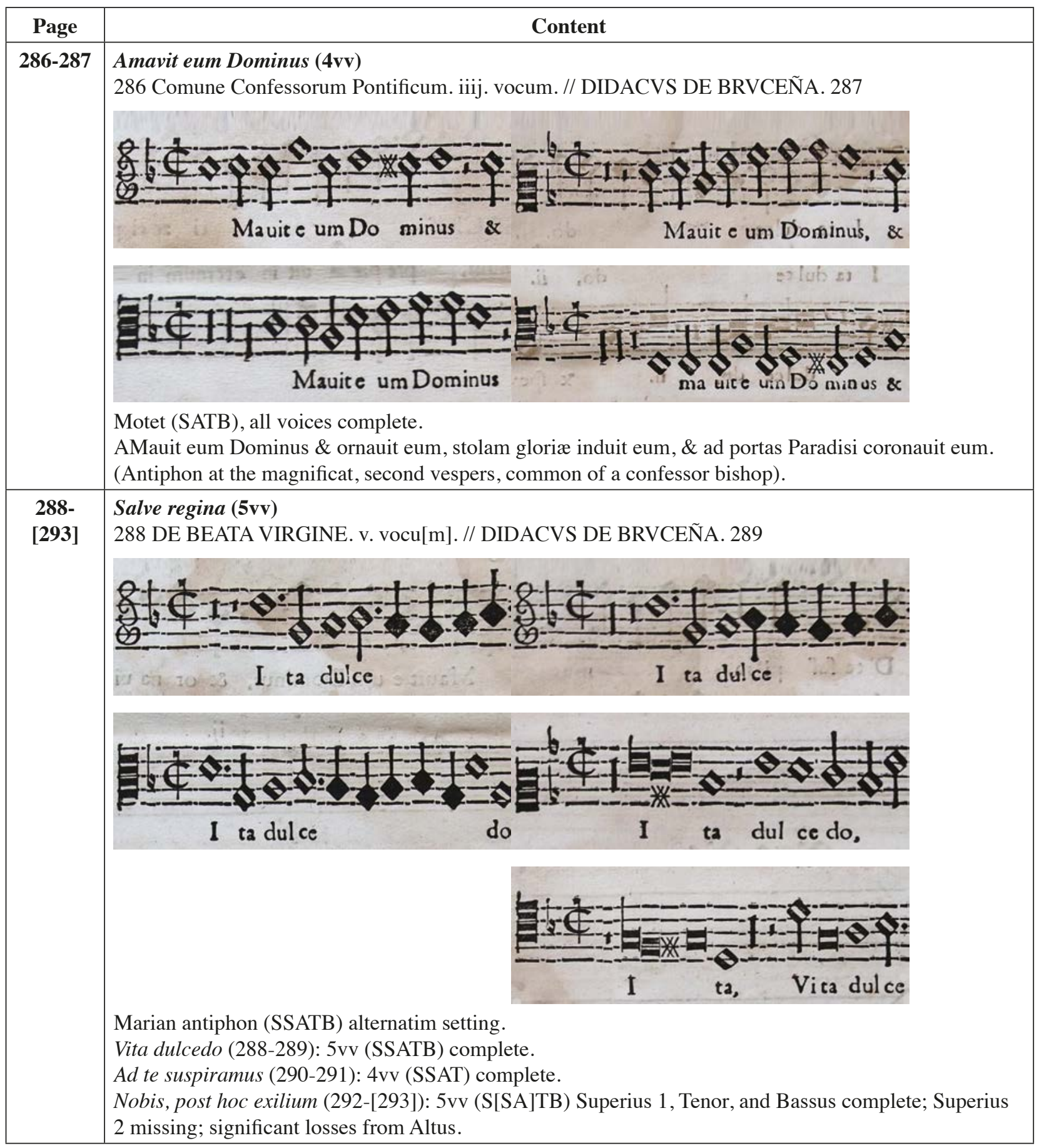




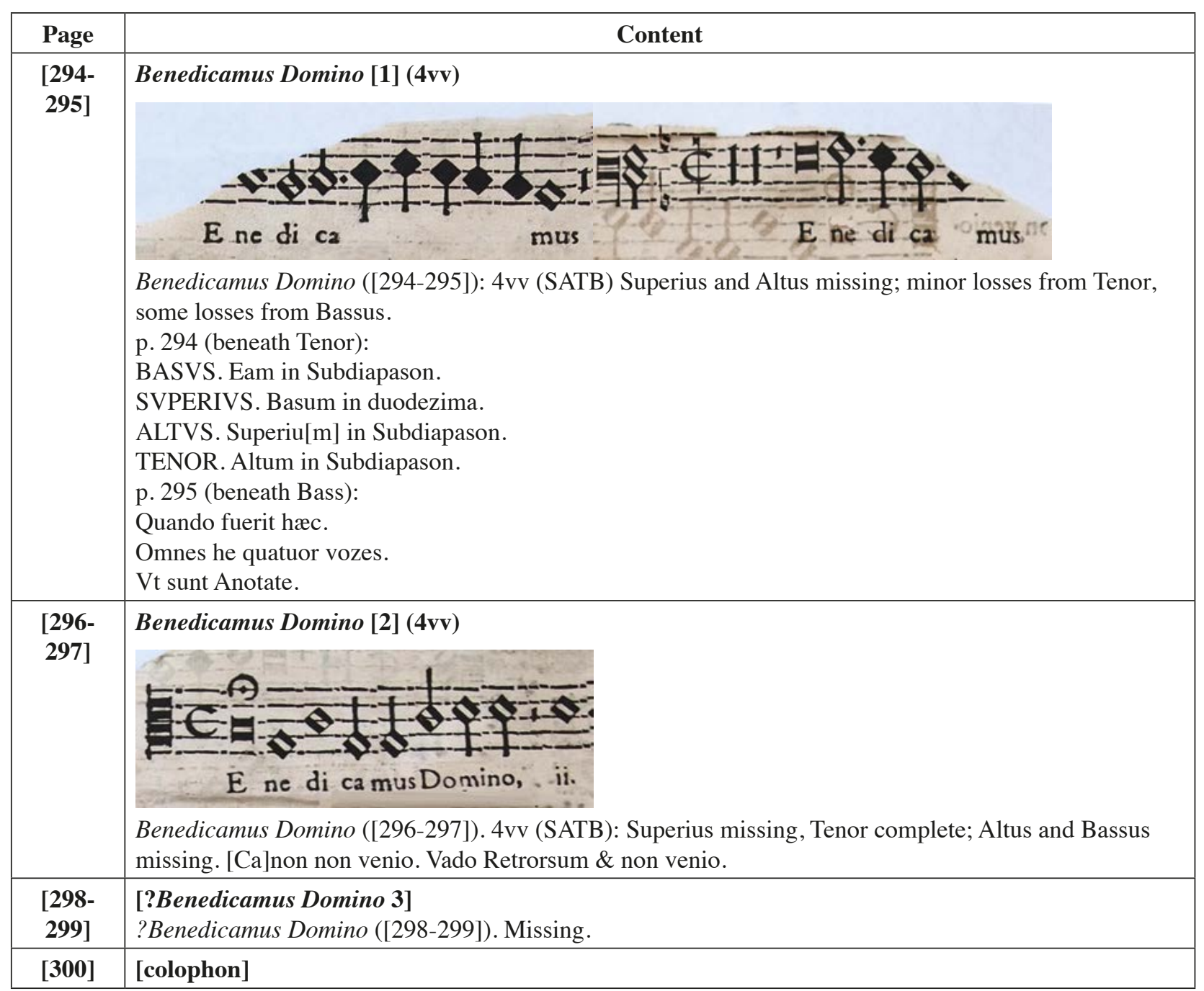




\section{WORKS CITED}

Bécares Botas, Vicente. Avance para una guía del mundo del libro salmantino del siglo XVI. Zamora: Ediciones Monte Casino, 2002.

—. Guía documental del mundo del libro salmantino del siglo XVI. Segovia: Fundación Instituto Castellano y Leonés de la Lengua, 2006.

Ballone, Angela. The 1624 tumult of Mexico in perspective (c. 1620-1650). Leiden: Brill, 2018.

Casado Arboniés, Manuel. "Pérez de la Serna, Juan", Diccionario biográfico español. Madrid: Real Academia de la Historia, 2009-2013, vol. 41, pp. 287-298.

Canguilhem, Philippe. "Singing upon the Book according to Vicente Lusitano". Early Music History, 30 (2011), pp. 55-103.

Cátedra García, Pedro Manuel and Anastasio Rojo Vega. Bibliotecas y lecturas de mujeres: $s . X V I$. Salamanca: Instituto de Historia del Libro y de la Lectura, 2004.

Ceremonias, usos, costumbres y señales de la congregacion de san Benito el Real de Valladolid. Valladolid: Andrés Merchán, 1599.

Cervera Vera, Luis. Las Estampas de El Escorial por Juan de Herrera. Madrid: Editorial Tecnos, 1954.

Civitas: Exposición organizada con motivo del 1100 aniversario de la restauración de la ciudad de Zamora. Zamora: Junta de Castilla y León, 1993.

Corbeto, Albert. "Las musas ignoradas. Estudio historiográfico del papel de la mujer en el ámbito de la imprenta" in Muses de la Impremta. La dona i les arts del llibre. Segles XVI-XIX, ed. Marina Garone Gravier and Albert Corbeto López. Barcelona: Museu Diocesà de Barcelona/Associació de Bibliòfils de Barcelona, 2009, pp. 21-42.

Cortés Corral, Mónica and Victoria Méndez Viar. "Impresoras madrileñas en el Siglo de Oro: Juana Martínez de Angulo". Anexos de Signo, 4 (2001), pp. 185-211.

Cruickshank, Don W. "Some aspects of Spanish book-production in the Golden Age". The Library, 5th Series, 31/1 (1976), pp. 1-19.

Cuesta Gutiérrez, Luisa. La imprenta en Salamanca. Avance al estudio de la tipografía salmantina (1480-1944). Salamanca: Diputación Provincial de Salamanca, 1960.

Delgado Casado, Juan. Diccionario de impresores españoles: (siglos XV-XVII), 2 vols. Madrid: Arco Libros, 1996.
Duro Peña, Emilio. La música en la Catedral de Orense. Orense: Caixa Ourense, 1996.

Establés Susán, Sandra. Diccionario de mujeres impresoras y libreras de España e Iberoamérica entre los siglos XV y XVIII. Zaragoza: Prensas de la Universidad de Zaragoza, 2018.

Fenlon, Iain. "Artus Taberniel: Music Printing and the Book Trade in Renaissance Salamanca", in Early Music Printing and Publishing in the Iberian World, ed. Iain Fenlon and Tess Knighton. Kassel: Reichenberger, 2006, pp. 117-146.

Fuente Charfolé, José Luis de la. "Inventarium librorum musicae: nueva aportación documental sobre el archivo musical de la catedral de Cuenca (siglos XVII-XVIII)". Anuario Musical, 62 (2007), pp. 171-204.

Garbayo Montabes, Francisco Javier. Catálogo del archivo de música de la Catedral de Ourense. Santiago de Compostela: Instituto Galego das Artes Escénicas e Musicais, Xunta de Galicia, 2004.

García Fraile, Dámaso. Vivanco, Sebastián. Libro de motetes (1610). Estudio y transcripción, 2 vols. Salamanca: Fundación Las Edades del Hombre, 20012002.

Gómez-Moreno, Manuel. Catálogo monumental de España. Provincia de Zamora (1903-1905). Madrid: Ministerio de Instrucción Pública y Bellas Artes, 1927.

López-Calo, José. La música en la Catedral de Zamora. Zamora: Diputación de Zamora, 1985.

__ La música en la Catedral de Burgos, 14 vols. Burgos: Caja de Ahorros del Círculo Católico Burgos, 1995.

—. "Briceña [Briceño, Bruceña], Diego", in Diccionario de la música española e hispanoamericana, 10 vols., ed. Emilio Casares Rodicio. Madrid: Sociedad General de Autores y Editores, 1999-2002, vol. 1, p. 696.

López Serrano, Matilde. "El grabador Pedro Perret", in $E l$ Escorial, 1563-1963, IV Centenario de la fundación del Monasterio de San Lorenzo el Real. Madrid: Ediciones Patrimonio Nacional, 1963, pp. 689-716.

Lorenzo Pinar, Francisco Javier and Luis Vasallo Toranzo, "D. Juan Pérez de la Serna, Arzobispo de México y Obispo de Zamora (c. 1566-1631)", Zamora y América. Actos de las Jornadas celebradas en Zamora los días 4, 5 y 6 de abril de 1991. Zamora: Diputación Provincial de Zamora, Instituto de Es- 
tudios Zamoranos "Florián de Ocampo", 1992, pp. 523-37.

Luis Iglesias, Alejandro. En torno al barroco musical español: el oficio y la misa de difuntos de Juan García de Salazar. Salamanca: Ediciones Universidad de Salamanca y Colegio Universitario de Zamora, 1989. - "El maestro de capilla Diego de Bruceña (1567/71-1623) y el impreso perdido de su libro de Misas, Magnificats y Motetes (Salamanca: Susana Muñoz, 1620)", in Encomium musicae: Essays in Memory of Robert J. Snow, ed. David Crawford. Hillsdale, NY: Pendragon, 2002, pp. 435-469.

Marín López, Javier. "Cinco nuevos libros de polifonía en la Catedral Metropolitana de Ciudad de México". Historia Mexicana, 52/4 (2003), pp. 1073-1094.

Martín Valle, Jorge. “Alonso de Tejeda (c. 1540-c.1628) y el liber tertius sacrarum cantionum: descripción y análisis". Anuario del Instituto de Estudios Zamoranos Florián de Ocampo, 29 (2012-2014), pp. 411-461.

Nelson, Bernadette. "From Anchieta to Guerrero: The Salve Regina in Portuguese Sources and an Unknown Early Spanish Alternatim Setting”. Revista Portuguesa de Musicologia, 6 (2019), pp. 113-156.

Noone, Michael and Graeme Skinner, eds. Sebastián de Vivanco: Liber Magnificarum (1607). Middleton, Wisconsin: A-R Editions, 2020.

O'Connor, Michael. "The Polyphonic Marian Antiphon in Renaissance Spain", in Treasures of the Golden Age, ed. Michael O'Connor and Walter Clark. Hillsdale, NY: Pendragon, 2012, pp. 87-115.

Milsom, John. “The T-Mass: quis scrutatur?”. Early Music, 46/2 (2018), pp. 319-331.

Parker, Mike, K. Melis and Hendrick D. L. Vervliet. "Typographica Plantiniana III. Ameet Tavernier. Punchcutter (ca. 1522-1570". De Gulden Passer, 39 (1961), pp. 17-76.

Pedrell, Felipe. "Bruceña, (Diego)", in Diccionario biográfico y bibliográfico de músicos y escritores de música españoles. [Barcelona: Tip. de V. Berdós y Feliu, 1894-97], Vol. 1, p. 228.

Pérez Martín, Sergio and Rubén Fernández Mateos. “"El Maestro de la Virgen de la Calva': un escultor/taller al servicio de la monarquía castellanoleonesa y del alto clero de Zamora". Studia Zamorensia, 14 (2015), pp. 79-107.

Portal Monge, Yolanda and María Paz de Sena Espinel. "Artistas y artesanos del libro en la Salamanca del
XVI a través de los libros parroquiales de bautismo". Memoria Ecclesiae, 9 (1996), pp. 221-257.

Preciado, Dionisio. "Cantus firmus 'ostinati' de Alonso de Tejeda”. Tesoro sacro musical (1972), pp. 48-50.

- Alonso de Tejeda (ca. 1556-1628), polifonista español, 2 vols. Madrid: Editorial Alpuerto, 1974 and 1977.

Primeira parte do index da Livraria de musica do muyto alto e poderoso Rey Dom Ioão ó IV. Nosso Senhor. Lisbon: Paulo Craesbeek, 1649.

Ramos de Castro, Guadalupe. La Catedral de Zamora. Zamora: Fundación Ramos de Castro para el Estudio y Promoción del Hombre, 1982.

Robben, Frans M. A. "Jan Poelman: boekverkoper en vertegenwoordiger van de firma Plantin-Moretus in Salamanca 1579-1607”. De Gulden passer, 71-72 (1993-1994), pp. 5-370.

Rodrigues Mourinho, António. "Obra inédita de un músico español e Portugal”. Patrimonio - Revista de patrimonio y turismo cultural, 58 (2016), pp. 36-38.

Ruiz Fidalgo, Lorenzo. La imprenta en Salamanca (15011600), 3 vols. Madrid: Arco Libros, 1994.

Sabbe, Maurits. Ameet Tavernier. The Hague: Nijhoff, 1923.

Signer, Emanuel. "Tradition and Experimentation in Choirbooks Printed in Late Sixteenth- and Seventeenth-Century Italy", in Sounding the Past: Music as History and Memory, ed. Karl Kügle. Turnhout: Brepols Publishers NV, 2020, pp. 157-190.

Stevenson, Robert Murrell. Spanish cathedral music in the Golden Age. Berkeley: University of California Press, 1961.

_- La música en las catedrales españolas del Siglo de Oro. Madrid: Alianza Editorial, 1993.

Snow, Robert J. The 1613 Print of Juan Esquivel Barahona. Detroit: Detroit Monographs in Musicology, 1978.

Snow, Robert J., ed. A New-World Collection of Polyphony for Holy Week and the Salve Service: Guatemala City, Cathedral Archive, Music MS 4. Monuments of Renaissance Music, vol. 9. Chicago \& London: University of Chicago Press, 1996.

Stratton, Suzanne L. The Immaculate Conception in Spanish Art. Cambridge: Cambridge University Press, 1994.

Valdenebro y Cisneros, José María de. La imprenta en Córdoba. Ensayo bibliográfico. Madrid: Sucesores de Rivadeneyra, 1900. 
Wilkinson, Alexander Samuel and Alejandra Ulla Lorenzo, eds. Iberian Books Volumes II \& III: Books Published in Spain, Portugal and the New World or elsewhere in Spanish or Portuguese between 1601 and 1650 / Libros Ibéricos volúmenes II y III: Libros publicados en España, Portugal y el Nuevo Mundo o impresos en otros lugares en español o portugués entre 1601 y 1650. Leiden: Koninklijke Brill NV, 2016.
Wilkinson Zerner, Catherine and C. P. M. Brown et al. Philip II and the Escorial: Technology and the representation of Architecture. An Exhibition by the Department of Art, Brown University, January 27 through March 4, 1990. Providence, Rhode Island: Brown University, 1990.

Recibido: 07.09.2020

Aceptado: 17.09.2020 